ZOOLOGIA 31 (6): 599-620, December, 2014

http://dx.doi.org/10.1590/S1984-46702014000600007

\title{
Cerambycidae (Coleoptera) from state of Maranhão, Brazil. IV: new genus, new species, new synonym, new records
}

\author{
Ubirajara R. Martins' ${ }^{1}$, Antonio Santos-Silva ${ }^{1}$, \\ Maria Helena M. Galileo ${ }^{2} \&$ Francisco L. De Oliveira ${ }^{3}$
}

\author{
${ }^{1}$ Museu de Zoologia, Universidade de São Paulo. Caixa Postal 42494, 04218-970 São Paulo, SP, Brazil. \\ E-mail: urmsouza@usp.br; toncriss@uol.com.br \\ 2 PPG Biologia Animal, Departamento de Zoologia, Universidade Federal do Rio Grande do Sul. Av. Bento Gonçalves 9500, \\ prédio 43435, 91501-970 Porto Alegre, RS, Brazil. E-mail: galileomh@yahoo.com \\ ${ }^{3}$ Departamento de Química e Biologia, Centro de Estudos Superiores de Caxias, Universidade Estadual do Maranhão. \\ Praça Duque de Caxias, Morro do Alecrim, 65604-380 Caxias, MA, Brazil. E-mail: franciscolimeira@CESC.uema.br
}

\begin{abstract}
Five new species and one new genus of Cerambycidae are described from Maranhão: Mirador ayrii gen. nov., sp. nov.; Stizocera ignea sp. nov.; Engyum vicinum sp. nov.; Thoracibidion rubripenne sp. nov.; Polyrhaphis ju sp. nov. Sphagoeme Aurivillius, 1893 is proposed as a new synonym of Limernaea Thomson, 1878, and Sphagoeme nigrotibialis Martins, 1973 is proposed as a new synonym of Limernaea picta Thomson, 1878. A total of 102 known species are recorded for the state of Maranhão for the first time: two Prioninae, 69 Cerambycinae and 31 Lamiinae. Six species are reported for the first time from Brazil. With these new records, and the five new species described, the total number of species recorded from the state of Maranhão increased from 367 to 474.
\end{abstract}

KEY WORDS. Cerambycidae fauna; Neotropical; new taxa; taxonomy.

This is the fourth contribution to the study of the fauna of Cerambycidae from the Brazilian state of Maranhão. The first three publications of this series (MARTINs et al. 2009a, 2009b, 2011) compiled a total of 367 species.

During the last few years, the fourth author has systematically collected in the state of Maranhão. He has sent the Cerambycidae to the MZSP (see below) for identification on a regular basis, and each batch has resulted in new discoveries that have been published separately.

According to Martins et al. (2009a), Zajciw (1967) was the first author to publish a list of the species of Cerambycidae occurring in Maranhão, especially in São Luís and surrounding area. Also according to MArTins et al. (2009a) [translated]: "We found species linked with the Equatorial Domain = Equatorial Amazon forest (39 species or 33.6\%), linked with the Tropical Atlantic plus "Cerrado" Domains (27 species or 23.3\%), and widely distributed species, that is, species with records from two or more domains (45 species or $38.8 \%$ ). This distribution led us to believe that the gallery forests of the state of Maranhão have elements of the Amazon Forest and of the Atlantic Forest ("Cerrado"), making the region particularly interesting. Furthermore, only two species (1.7\%) are recorded from the Brazilian Northeast (perhaps linked to the Domain of the "Caatingas"), three (2.6\%) of which are new and are known only from their type localities." The specimens studied herein are from the same area as the specimens examined by MARTINS et al. (2009a), expanding our understanding of their distribution in the state.

The specimens are deposited at the "Coleção Zoológica do Maranhão, Universidade Estadual do Maranhão, Caxias (UEMA)". Additionally, the type material will be deposited in Museu de Zoologia, Universidade de São Paulo, São Paulo (MZUSP).

\section{TAXONOMY}

In this work a total of 102 species of Cerambycidae are recorded for the first time from the Brazilian state of Maranhão: two Prioninae, 69 Cerambycinae and 31 Lamiinae. This raises the total number of species occurring in the state, including the five new species, to 474 .

\section{Synonymy between Limernaea Thomson, 1878 and Sphagoeme Aurivillius, 1893}

MarTins et al. (2009a) listed Sphagoeme nigrotibiallis Martins, 1973 from the state of Maranhão. Herein we propose synonyms and transfers associated with this species as explained below.

THomson (1878a) described Limernaea as follows: "Corpus elongatum, parallelum, subdepressum; antennae artic. $3^{\circ}$ sequente longiore; palpi breves, aequales; prothorax elongatus, cylindricus, inermis, lateribus tumidus; pedes subgraciles, postici elongati; tarsi mediocres". According to Thomson (1878a: 3), Limernaea was best classified in Obriini:

2014 Sociedade Brasileira de Zoologia | www.sbzoologia.org.br | www.scielo.br/zool All content of the journal, except where identified, is licensed under a Creative Commons attribution-type BY-NC. 
"Les 18 genres nouveaux dont l'on trouvera la description plus loin, ont été créés aux dépens des OBRIUM de notre collection et coupes limithrophes". In his description, he spelled the genus name as Limernaea. However, when he described the only species of the genus, he used Lymernaea picta. After that, he used both names: Lymernaea (THOMson 1878a: 21 description of Urorcites); Limernaea (Thomson 1878b: 2); Lymernaea (THOMson 1878b: 3).

Lameere (1883) listed Lymernaea in Cerambycini (= Cerambycinae): "Lymernaea n. g. (Thomson, Rev. Zool., 1878, p. 20. [emend.]). Limernaea Thomson." Auriviluius (1912) and BLACKWELDER (1946) maintained the genus in Obriini Mulsant, 1839 (both used Lymernaea).

The only subsequent references to Limernaea (with this spelling) occurred in catalogs and checklists (except for MARtins \& Galileo 2003): Monné (1993) (Obriini); Monné \& Giesbert (1994) (Obriini); Monné \& Hovore (2005) (Hesperophanini); Monné \& Hovore (2006) (Hesperophanini); Bezark \& Monné (2013) (Hesperophanini); Monné (2014a) (Hesperophanini).

Martins \& Galileo (2003) transferred Limernaea from Obriini to Hesperophanini Mulsant, 1839, which they justified as follows (translated): "We examined a photograph of the holotype of L. picta, deposited at the Thomson collection, which is now housed at the Muséum national d'Histoire naturelle (MNHN, Paris, France). The holotype was photographed by Moure in September 1972. It is certainly not an Obriini, but most likely a species of Hesperophanini. The holotype was examined by G. Tavakilian, of the MNHN (personal communication), who also examined 3 male and 2 female deposited at the Gounelle collection (MNHN), all from "Santo Antonio da Barra" (Condeúba today), state of Bahia [Brazil], and collected by Gounelle himself on November-December 1888. He suggested that Limernaea was the same as Paraliostola Tavakilian \& Monné, 1991, also treated in this series (MARTINS 1999: 22). Therefore, Limernaea needs to be transferred to Hesperophanini".

Aurivillius (1893) described Sphagoeme in Oemini Lacordaire, 1868 to accommodate $S$. sahlbergi from Brazil: "Palpi breves, subaequales, apice truncati. - Frons subverticalis. Genae brevissimae. - Oculi nudi, prominuli, rude granulati; lobi superi parvi, angusti, late separati; lobi inferiores maximi, valde convexi, subglobosi. - Antennae graciles, corpore tertia parte longiores, basi late distantes... Prothorax subquadratus, lateribus medio angulato-dilatatis, supra deplanatus, parum inaequalis... Elytra omnino parallela, apice conjunctim late rotundata, inermia, supra subplana... Abdomen elongatum, segmentum primum reliquis paullo longius... Femora apicem versus modice compresso-dilatata, postica segmentum tertium abdominis haud vel parum superantia. Tibiae graciles... ơ. Prosternum utrinque ante coxas depressione magna, opaca, rhomboidali intructum... o. Prosternum simplex...".

Martins (1973) described Sphagoeme nigrotibialis (Fig. 5) based on a male specimen from Brazil (Minas Gerais). TAvaKILIAN
(2013) synonymized S. nigrotibialis with Limernaea picta, and maintained the latter in Hesperophanini. We agree with the synonym proposed, but it is not valid in TAVAKILIAN (2013) (ICZN 1999: article 8).

Given that Sphagoeme nigrotibialis is a true Oemini (and agrees perfectly with the original description of Sphagoeme), Limernaea picta (Figs 1-4) should be transferred to this tribe.
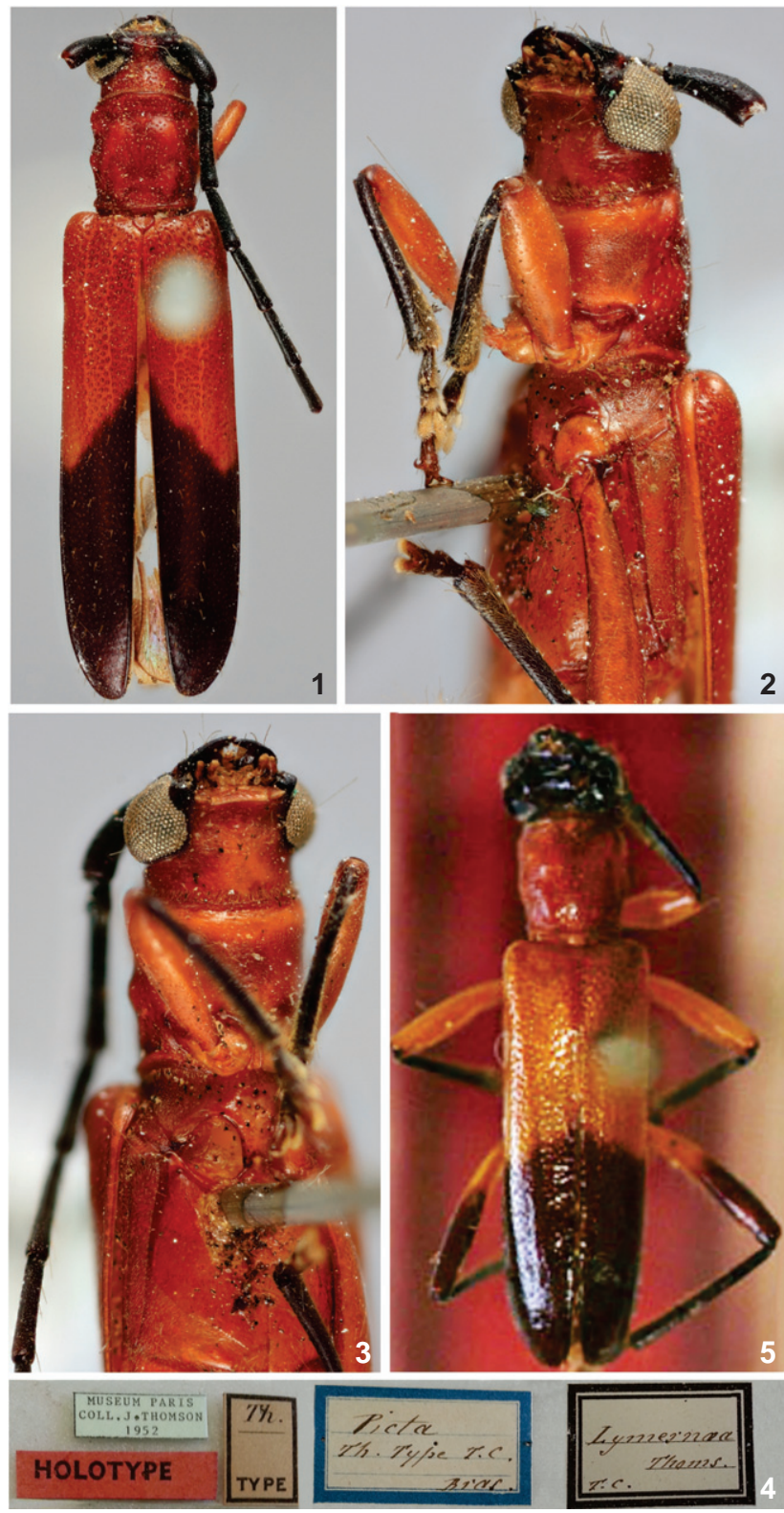

Figures 1-5. (1-4) Limernaea picta, holotype female: (1) dorsal view; (2) ventral view, left; (3) ventral view, right; (4) labels; (5) Sphagoeme nigrotibiallis, holotype male, dorsal view. Figures 1-4 by Eugenio Nearns. 
As the description of Sphagoeme nigrotibialis agrees with the original description and redescriptions of Sphagoeme (and consequently with the characters of the type species of Sphagoeme), and as that species is the same as Limernaea picta, Sphagoeme and Limernaea are synonyms. According to ICNZ (1999: Article 23), "the valid name of a taxon is the oldest available name applied to it..." Thus, Sphagoeme is a junior synonym of Limernaea, because both names are in current use (ICZN 1999: Article 23.9). Limernaea now includes the following species: L. acuta (Martins \& Galileo, 1994) comb. nov.; $L$. aurivillii (Gounelle, 1909) comb. nov.; L. lineata (Martins, 1981) comb. nov.; L. ochracea (Fisher, 1927) comb. nov.; L. paraensis (Martins, 1977) comb. nov.; L. picta (= S. nigrotibialis syn. nov.); L. premarginata (Dalens \& Touroult, 2014) comb. nov.; $L$. sahlbergi (Aurivillius, 1893) comb. nov. (= S. bicolor Zajciw, 1960); and L. suturalis (Martins, 1977) comb. nov.

There is no need to change the spelling of Limernaea to Lymernaea (ICZN 1999: Article 32.3). As seen above, the misspelling was repeated more than once by Thomson, always without any explanation.

As there is a recent redescription of Sphagoeme (MARTins 1997: 65), and it can be used to understand and characterize Limernaea, a new redescription is unnecessary.

\section{Prioninae Latreille, 1802 Macrotomini Thomson, 1861 Protorma costifera (Thomson, 1877)}

Material examined. BRAzIL, Maranhão: Bom Jardim (REBIO - Reserva Biológica do Gurupi), 1 female, 2-11.IX.2010, D.W.A. Marques, E.A.S. Barbosa, J.A. Silva \& M.M. Abreu leg., Malaise trap.

It was described from French Guiana and occurs in Colombia, Ecuador, Peru, Guyana, French Guiana, and Brazil (Amazonas, Pará) (ZAJCIW 1960; SANTOS-Silva \& GaliLeo 2011; MonNé 2014c).

\section{Physopleurus tritomicros Lameere, 1912}

Material examined. BRAzIL, Maranhão: Bom Jardim (REBIO - Reserva Biológica do Gurupi), 1 female, 1-5.I.2011, M.M. Abreu, E.A.S. Barbosa \& A.A. Santos leg., light trap.

It was described from French Guiana and later it was recorded from Brazil (Amazonas, Roraima) (Monné 2014c).

\section{Cerambycinae Latreille, 1802 Achrysonini Lacordaire, 1868 Achryson pictum Bates, 1870}

Material examined. BRAzIL, Maranhão: Bom Jardim (REBIO - Reserva Biológica do Gurupi), 1 male, 1-6.XI.2010, M.M. Abreu, J.A. Silva, G.A. Reis \& E.A.S. Barbosa leg., light trap.

It was described from Brazil (Pará) and French Guiana. It occurs in Colombia, Ecuador, Peru, Venezuela, Guyana,
Suriname, French Guiana, Bolivia, and Brazil (Amazonas, Pará, Amapá, Goiás, Mato Grosso) (Martins 2002; Monné 2014a).

Cerambycini Latreille, 1802

\section{Coleoxestia glabripennis (Bates, 1870)}

Material examined. BraziL, Maranhão: C.N. Maranhão (REBIO - Reserva Biológica do Gurupi; $03^{\circ} 14^{\prime} \mathrm{S}, 46^{\circ} 41^{\prime} \mathrm{W}$ ), 1 male, 07-15.I.2011, F.L. Oliveira, M.M. Abreu \& E.A.S. Barbosa leg., light trap.

It was described from Brazil (Pará) and occurs in Bolivia and the Brazilian state of Amapá (Martins \& Monné 2005, BeZARK \& Monné 2013). Zajciw (1972) recorded this species from Brazil (Rio de Janeiro) apparently based on an incorrectly identified specimen. However, the formal exclusion of occurrence of this species in southeastern Brazil has never been made.

\section{Coleoxestia vittata (Thomson, 1861)}

Material examined. BraziL, Maranhão: C.N. Maranhão (REBIO - Reserva Biológica do Gurupi; 03 $14^{\prime} \mathrm{S}, 46^{\circ} 41^{\prime} \mathrm{W}$ ), 1 male, 1-5.VII.2011, M.M. Abreu \& J.A. Silva leg., light trap.

It was described from Brazil. It occurs in Guatemala, Honduras, Costa Rica, Panama, Bolivia, Brazil (Goiás, Bahia, Minas Gerais, Espírito Santo, Rio de Janeiro, São Paulo, Paraná, Santa Catarina, and Rio Grande do Sul), Paraguay, and Argentina (Eya \& Chemsak 2005; Martins \& Monné 2005; Bezark \& Monné 2013).

\section{Criodion rhinoceros Bates, 1870}

Material examined. BRAzIL, Maranhão: Bom Jardim (REBIO - Reserva Biológica do Gurupi), 1 female, 1-5.I.2011, M.M. Abreu, E.A.S. Barbosa \& A.A. Santos leg., light trap.

It was described from Brazil (Pará) and recorded from the Brazilian state of Amazonas, Ecuador, and Peru (Demez \& Touroult 2012, Bezark \& Monné 2013).

\section{Sphallotrichus spadiceus (Gahan, 1892)}

Material examined. Brazil, Maranhão: Caxias (Campus UEMA, Morro do Alecrim), 1 female, 1-3.VI.2010, A.S. Silva \& K.S. Lobo leg.; 1 female, 25-30.VI.2010, F.L. Oliveira leg.; Fortaleza dos Nogueiras (Fazenda Santa Maria; Estação Experimental Agroserra), 1 male, 7-14.V.2010, A.S. Silva \& K.S. Lobo leg.

It was described from Brazil and occurs in Brazilian states of Goiás, Bahia, Minas Gerais, Espírito Santo, Rio de Janeiro, Paraná, Santa Catarina, and Rio Grande do Sul, as well as from Argentina (Duffy 1960, Martins \& Monné 2005, Monné 2014a).

\section{Clytini Mulsant, 1839}

\section{Mecometopus polygenus Thomson, 1861}

Material examined. BraziL, Maranhão: Bom Jardim (REBIO - Reserva Biológica do Gurupi), 1 female, 1-6.XI.2010, M.M. Abreu, J.A. Silva, G.A. Reis \& E.A.S. Barbosa leg., light trap. 
It was described from Brazil (Amazon region). It occurs in Ecuador, Peru, Bolivia, French Guiana, and Brazil (Amazonas, Pará) (Demez \& Touroult 2012, Bezark \& Monné 2013).

\section{Compsocerini Thomson, 1864 Aglaoschema albicorne (Fabricius, 1801)}

Material examined. Brazil, Maranhão: C.N. Maranhão (REBIO - Reserva Biológica do Gurupi; 0314'01"S, 4640'52"W), 1 male, 3-7.V.2011, F.L. Oliveira \& R.M.P. Campos leg., entomological trap.

It was described from "America meridionali". It occurs in Peru, Venezuela, French Guiana, and Brazil (Amazonas, Pará) (NAPP 2007).

\section{Aglaoschema apixara Napp, 2007}

Material examined. Brazil, Maranhão: Caxias (Bairro Pirajá; Sítio Edmar Brazil), 1 male, 2 females, 14-21.III.2006, M.J.A. Holanda leg., entomological trap containing orange juice; (Bairro Nova Caxias), 1 male, 22-29.VII.2005, M.J.A. Holanda leg., entomological trap containing orange juice; 2 females, 19.I-03.II.2006, M.J.A. Holanda leg., entomological trap containing orange juice; (Bairro Alto da Cruz), 1 female, 19.I03.II.2006, M.J.A. Holanda leg., pet trap; (Bairro Fumo Verde; Chácara Pazárgada), 1 female, 07-14.II.2006, M.J.A. Holanda leg., entomological trap; 1 male, 14-21.II.2006, M.J.A. Holanda leg., entomological trap containing orange juice; (Bairro Baixinha), 1 female, 21.II-07.III.2006, M.J.A. Holanda leg., entomological trap containing orange juice.

This species was described from Brazil (Bahia, Minas Gerais, and Espírito Santo) and no additional country records have been found (Monné 2014a).

\section{Orthostoma abdominale (Gyllenhal, 1817)}

Material examined. Brazil, Maranhão: Caxias (Bairro Alto da Cruz), 2 females, 19.I-3.II.2006, M.J. Almeida-Holanda leg.; (Bairro Nova Caxias), 1 male, 5-12.VIII.2005, M.J. AlmeidaHolanda leg.; 3 males, 10 females, 19.I-3.II.2006, M.J. AlmeidaHolanda leg.; 3 males, 1 female, 30.VI-10.VII.2006, M.J. Almeida-Holanda leg.; 2 males, 1 female, 10-17.VII.2006, M.J. Almeida-Holanda leg.; (Bairro Itapecuruzinho, Chácara Pazárgada), 2 females, 7-14.II.2006, M.J. Almeida-Holanda leg.; 4 males, 19 females, 10.17.VII.2006, M.J. Almeida-Holanda leg.; 1 male, 2 females, 17-24.VII.2006, M.J. Almeida-Holanda leg.; female, 24-VII.2-VIII.2006, M.J. Almeida-Holanda leg.; (B. Baixinha), 1 male, 2 females, 10-15.VII.2005, M.J. AlmeidaHolanda leg.; 2 females, 22-29.VII.2005, M.J. Almeida-Holanda leg.; 1 male, 13-19.I.2006, M.J. Almeida-Holanda leg.; 1 male, 2 females, 19.I-3.II.2006, M.J. Almeida-Holanda leg.; 2 females, 14-21.II.2006, M.J. Almeida-Holanda leg.; 3 females, $17-$ 24.VII.2006, M.J. Almeida-Holanda leg.; 1 female, 7-14.II.2008, M.J. Almeida-Holanda leg.; (Bairro Fumo Verde), 1 male, 714.II.2006, M.J. Almeida-Holanda leg.; (Campus UEMA, Morro do Alecrim), 1 female, 1-5.I.2009, F.L. Oliveira leg., white light. It was described from "Isle de France" and was recorded for the first time from Brazil by SCHÖNHERR (1817): "Abdominalis. Nov. Spec. - vid. App. p. 157. 216. Loc. Isle de France, Brazilia". It occurs in Colombia, Ecuador, Peru, Brazil (Amazonas, Pará, Acre, Rondônia, Mato Grosso, Mato Grosso do Sul, Goiás, Bahia, Minas Gerais, Espírito Santo, Rio de Janeiro, São Paulo, Paraná, Santa Catarina, and Rio Grande do Sul), Bolivia, Paraguay, and Argentina (Monné 2014a).

\section{Eburiini Blanchard, 1845 Cupanoscelis clavipes Gounelle, 1909}

Material examined. BraziL, Maranhão: Mirador (Parque Estadual Mirador, Base da Geraldina, $\left.06^{\circ} 37^{\prime} 25^{\prime \prime} \mathrm{S}, 45^{\circ} 52^{\prime} 08^{\prime \prime} \mathrm{W}\right)$, 1 male, 1 female, 12-20.X.2012, F.L. Oliveira, L.S. Santos \& C.F. Barros leg., light trap.

It was described from Brazil (Goiás) and occurs in Bolivia, Brazil (Goiás), and Argentina (Monné 2014a).

\section{Eburiaca sinopia Martins, 2000}

Material examined. Brazil, Maranhão: Mirador (Parque Estadual Mirador, Base da Geraldina, $\left.06^{\circ} 37^{\prime} 25^{\prime \prime} \mathrm{S}, 45^{\circ} 52^{\prime} 08^{\prime \prime} \mathrm{W}\right)$, 1 female, 12-20.X.2012, F.L. Oliveira, L.S. Santos \& C.F. Barros leg., light trap.

This species was known only from Brazil (Mato Grosso) (Monné 2014a).

\section{Eburodacrys obscura Martins, 1973}

Material examined. BraziL, Maranhão: Mirador (Parque

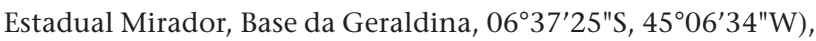
5 males, 12-20.X.2012, F.L. Oliveira, L.S. Santos \& C.F. Barros leg., light trap.

It was described from Brazil (São Paulo) and known only from this Brazilian state (BeZARK \& Monné 2013).

\section{Eburodacrys prolixa Monné \& Martins, 1992}

Material examined. BRAzIL, Maranhão: C.N. Maranhão (REBIO - Reserva Biológica do Gurupi), 1 female, 2-11.IX.2010, F.L. Oliveira, J.C. Silva, J.A. Silva \& M.M. Abreu leg., light trap; $\left(03^{\circ} 14^{\prime} 01^{\prime \prime S}, 46^{\circ} 40^{\prime} 52^{\prime \prime} \mathrm{W}\right), 1$ female, 1-5.VII.2011, F.L. Oliveira $\&$ D.W.A. Marques leg., light trap.

It was described and known only from Brazil (Rondônia and Mato Grosso) (Monné 2014a).

\section{Eburodacrys tuberosa Gounelle, 1909}

Material examined. BraziL, Maranhão: Caxias (Campus UEMA, Morro do Alecrim), 1 male, 25-31.I.2009, F.L. Oliveira leg., white light.

It was described from Brazil (Goiás and Minas Gerais)and occurs in Brazil (Piauí, Goiás, Mato Grosso do Sul, Minas Gerais, and São Paulo) and Argentina (Monné 2014a). 


\section{Ectenessini Martins, 1998 Mirador gen. nov.}

Type species: Mirador ayrii sp. nov.

Head elongate behind eyes. Upper eye lobes with 4 rows of ommatidia; lower eye lobes protruding, occupying most of lateral portion of head. Antennal tubercles separated by distance equal to width of one tubercle; apex rounded. Mandibles about one-third length of head; outer surface rounded. Last segment of labial and maxillary palps of males securiform. Antennae with 11 segments; reaching beyond elytral apex in male; basal antennomeres with long setae, as long as three times antennomere width; antennomere III conspicuously longer than scape and antennomere IV, without sulcus at dorsal portion of base.

Prothorax longer than wide; laterally round, without tubercles. Pronotum flattened on disk. Prosternal process conspicuously narrow medially, enlarged and truncate apically. Mesosternal process approximately as wide as one-third of mesocoxal cavity. Procoxal cavities open posteriorly. Elytra pubescent, lateral margins parallel; apex truncate. Procoxa without flaps. Protrochanter without modifications. Profemur fusiform, without keel on anterior half; meso- and metafemora subclavate. Meso- and metatarsomere I approximately as long as II-III together.

Etymology. Refers to the type locality of the type species. Masculine gender.

Remarks. Mirador gen. nov. differs from all other genera of Ectenessini (except for Meryeurus Martins, 1998) by the basal antennomeres having setae as long as three times the width of an antennomere. It differs from Meryeurus by the antennomere III without a sulcus on dorsal portion of base and prothorax conspicuously longer.

Mirador can be included in the alternative of couplet " 8 " from Martins (1998) (modified):

8(7). Upper eye lobes with three rows of ommatidia Bomarion Gounelle, 1909

- Upper eye lobes with more than three rows of ommatidia.....8a

$8 \mathrm{a}(8)$. Basal antennomeres with setae as long as three times the width of antennomere Mirador gen. nov.

- Basal antennomeres with setae from shorter to slightly longer than the width of antennomere (at most about twice longer)

$8 \mathrm{~b}(8 \mathrm{a})$. Upper eye lobes narrower than one-third of length of scape; elytra with rows of setae ........ Ectenessa Bates, 1885

- Upper eye lobes wider than one-third of length of scape; elytral setae not in rows ........... Lembu Galileo et al., 2014

\section{Mirador ayrii sp. nov. Figs 6-9}

Holotype male. Integument brownish-orange. Frons with thick, shallow, sparse punctures; area between antennal tubercles and margin of prothorax with moderately fine punc- tures; area behind eyes with punctures more abundant, anastomosed, coarser than on vertex; pubescence short, not obliterating integument, interspersed with long, sparse setae. Upper eye lobes with four rows of ommatidia; distance between upper eye lobes 0.70 times length of scape; distance between lower eye lobes, in frontal view, equal to 0.85 times length of scape. Outer surface of mandibles pubescent on basal half, with long, abundant setae. Length of antennae 1.95 times elytral length; reaching elytral apex at basal third of antennomere IX; scape, pedicel and antennomeres with long setae, longer and more abundant up to antennomere VII; antennal formula based on length of antennomere III: scape $=0.67$, pedicel $=0.22$, $\mathrm{IV}=0.72, \mathrm{~V}=0.80, \mathrm{VI}=0.75, \mathrm{VII}=0.80, \mathrm{VIII}=0.75, \mathrm{IX}=0.65$, $\mathrm{X}=0.55, \mathrm{XI}=0.75$.

Pronotum with longitudinal central sulcus, laterally microsculptured; punctures thin, abundant on lateral portion of smooth and glabrous area along longitudinal sulcus; area around glabrous region with sericeous pubescence, interspersed with long setae. Laterals of pronotum and most of prosternum with coarse, deep, abundant punctures; pubescence sericeous, setae long and sparse; anterior third of prosternum glabrous, transversely striated. Elytra with sericeous pubescence, interspersed with long setae; punctures coarse, moderately sparse on basal half, gradually sparser toward apex. Metepisterna finely pubescent. Laterals of metasternum pubescent; remaining areas with short, decumbent, sparse setae (particularly toward center). Femora, tibiae and tarsi with long, sparse setae. Urosternites with short, sparse setae, interspersed with long setae.

Dimensions in mm (male). Total length 6.0; length of prothorax at center 1.4; anterior width of prothorax 0.9 ; posterior width of prothorax 0.8; humeral width 1.4; elytral length 3.8.

Type material. Holotype male, BraziL, Maranhão: Mirador (Parque Estadual Mirador, Base da Geraldina, 06 $37^{\prime} 25^{\prime \prime S}$,

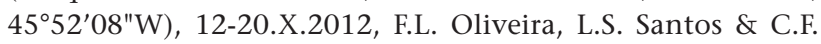
Barros leg. (MZUSP).

Etymology. Tupi, ayrií = little; not Latinized adjective. Relating to the size of the holotype.

\section{Niophis aper (Germar, 1824)}

Material examined. BRAzIL, Maranhão: Caxias (Campus UEMA, Morro do Alecrim), 1 female, 15-25.I.2009, F.L. Oliveira leg., white light; 1 female, 17.XII.2010, F.L. Oliveira leg., entomological net.

Described from Brazil, without detailed locality. It occurs in the sates of Pernambuco, Alagoas, Bahia, and Espírito Santo (Martins \& Galileo 2004).

\section{Elaphidiini Thomson, 1864 Anelaphus robi Hrabovsky, 1987}

Material examined. BRAzIL, Maranhão: Bom Jardim (REBIO - Reserva Biológica do Gurupi), 1 male, 1 female, 2-11.IX.2010, F.L. Oliveira, J.C. Silva, J.A. Silva \& M.M. Abreu leg., light trap. 
This species was described from Brazil (Amazonas, Pará, and Mato Grosso). It occurs in French Guiana and the Brazilian state of Rondônia (MonNé 2014a).

\section{Aposphaerion longicolle Bates, 1870}

Material examined. BRAzIL, Maranhão: Açailândia (Bairro Pequiá), 1 male, 06.I.2011, F.L. Oliveira leg.; C.N. Maranhão (REBIO - Reserva Biológica do Gurupi, $\left.03^{\circ} 14^{\prime} \mathrm{S}, 46^{\circ} 41^{\prime} \mathrm{W}\right), 1$ female, 0715.I.2011, F.L. Oliveira, M.M. Abreu \& E.A.S. Barbosa leg., light trap.

This species was described from Brazil (Amazonas). It occurs in French Guiana and the Brazilian states of Pará and Mato Grosso (MonNé 2014a).

\section{Mephritus amictus (Newman, 1841)}

Material examined. BRAzIL, Maranhão: Bom Jardim (REBIO - Reserva Biológica do Gurupi), 1 female, 1-6.XI.2010, M.M. Abreu, J.A. Silva, G.A. Reis \& E.A.S. Barbosa leg., light trap.

This species was described from Brazil (Rio de Janeiro). It is recorded from the Brazilian states of Goiás, Bahia, Espírito Santo, Rio de Janeiro, São Paulo, and Santa Catarina (MonNÉ 2014a).

\section{Nyssicus quadriguttatus (Swederus, 1787)}

Material examined. BrazIL, Maranhão: Bom Jardim (REBIO - Reserva Biológica do Gurupi), 1 male, 2-11.IX.2010, F.L. Oliveira, J.C. Silva, J.A. Silva \& M.M. Abreu leg., light trap; 2 males, 1-6.XI.2010, F.L. Oliveira, M.M. Abreu, J.A. Silva, G.A. Reis \& E.A.S. Barbosa leg., light trap.

This species was described from Honduras. It occurs in Honduras, Ecuador, Peru, French Guiana, and Brazil (Amazonas, Pará, Rondônia, and Mato Grosso). The most recent catalogs (Monné 2014a; BeZARk \& Monné 2013) do not record this species from Honduras, although the type locality is this country. MarTins (2005a) commented about the type locality of Cerambyx (Stenocorus) quadriguttatus but did not formalize the exclusion of the species from the fauna of Honduras. Thus, the species must be maintained as also occurring in this country.

\section{Nyssicus rosalesi Joly \& Martínez, 1981}

Material examined. BRAzIL, Maranhão: Bom Jardim (REBIO - Reserva Biológica do Gurupi), 1 female, 2-11.IX.2010, F.L. Oliveira, J.C. Silva, J.A. Silva \& M.M. Abreu leg., light trap; Mirador (Parque Estadual Mirador, Base da Geraldina, $\left.06^{\circ} 37^{\prime} 25^{\prime \prime S}, 45^{\circ} 52^{\prime} 08^{\prime \prime W}\right), 1$ male, 12-20.X.2012, F.L. Oliveira, L.S. Santos \& C.F. Barros leg., light trap.

This species was described from Venezuela. It occurs in Ecuador, Venezuela, Bolivia, French Guiana, and Brazil (Rondônia) (Bezark \& Monné 2013; Monné 2014a).

\section{Protomallocera hilairei (Gounelle, 1909)}

Material examined. Brazil, Maranhão: Caxias (Campus UEMA, Morro do Alecrim), 1 male, 1-10.I.2010, F.L. Oliveira leg., white light.
This species was described from Brazil (Goiás and Pernambuco) and recorded from Suriname, Bolivia, Paraguay, and the Brazilian states of Mato Grosso, Mato Grosso do Sul, Minas Gerais, and São Paulo (Monné 2014a).

\section{Rhomboidederes minutus Napp \& Martins, 1984}

Material examined. Brazil, Maranhão: Caxias (Campus UEMA, Morro do Alecrim), 2 females, 15-25.I.2009, F.L. Oliveira leg., white light; 1 male, 25-31.I.2009, F.L. Oliveira leg., white light.

This species was described from Suriname and Brazil (Pará). It is also known from Ecuador, Colombia, Bolivia, and French Guiana (Monné 2014a).

\section{Sphaerion exutum (Newman, 1841)}

Material examined. BRAZIL, Maranhão: Bom Jardim (REBIO - Reserva Biológica do Gurupi), 1 male, 4 females, 2-11.IX.2010, F.L. Oliveira, J.C. Silva, J.A. Silva \& M.M. Abreu leg., light trap.

This species was described from Brazil (without detailed locality). It is recorded from the United States of America (Texas), Mexico (Chiapas), Brazil (Pará, Goiás, Bahia, Minas Gerais, Espírito Santo, Rio de Janeiro, São Paulo, and Santa Catarina), Uruguay, and Argentina (Monné 2014a).

\section{Stizocera armata Audinet-Serville, 1834}

Material examined. BraziL, Maranhão: Mirador (Parque Estadual Mirador, Base da Geraldina, 06 $\left.37^{\prime} 25^{\prime \prime} \mathrm{S}, 45^{\circ} 52^{\prime} 08^{\prime \prime} \mathrm{W}\right)$, 1 male, 17-21.II.2007, F.L. Oliveira leg., light trap; 1 female, 1220.X.2012, F.L. Oliveira, L.S. Santos \& C.F. Barros leg., light trap.

This species was described from Brazil (without detailed locality). It occurs in Bolivia, Brazil (Goiás, Mato Grosso do Sul, Bahia, Minas Gerais, Espírito Santo, Rio de Janeiro, São Paulo, Paraná, Santa Catarina, and Rio Grande do Sul), and Argentina (Bezark \& Monné 2013, Monné 2014a).

\section{Stizocera ignea sp. nov. Figs 10-13}

Holotype male. Integument orange; dorsal portion of head, genae, narrow strip around lower eye lobes, mandibles, antennae, apical fourth of elytra, trochanters, femora, tibiae and tarsi dark brown; urosternites III-V brown. Frons with shallow, inconspicuous punctures and short, sparse setae; coronal suture smoothly marked, almost indistinct beyond antennal tubercles. Vertex with fine, shallow, sparse punctures, except for transversal stripe next to prothorax, which is finely punctured-striated; setae very short, sparse (except for few long setae near upper eye lobes), longer, distinctly denser on punctured-striated band. Upper eye lobes with 6 rows of ommatidia; distance between upper eye lobes 0.5 times length of scape; distance between lower eye lobes 0.9 times length of scape. Length of antennae 2.1 times elytral length; reaching elytral apex at basal third of antennomere 

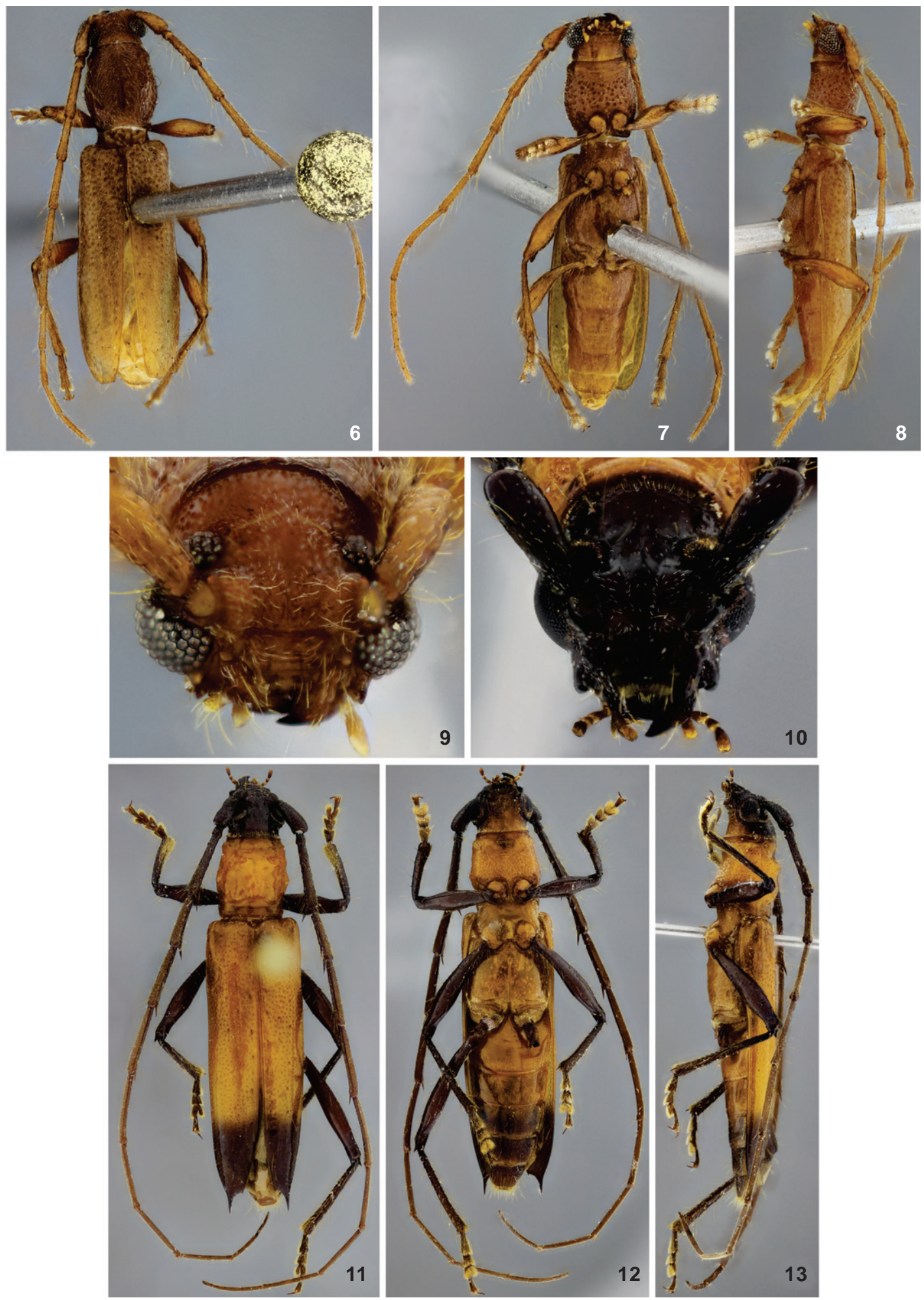

Figures 6-13. (6-9) Mirador ayrii sp. nov., holotype male: (6) dorsal view; (7) ventral view; (8) lateral view; (9) head, frontal; (10-13) Stizocera ignea sp. nov., holotype male: (10) head, frontal; (11) dorsal view; (12) ventral view; (13) lateral view. 
VIII; scape as long as 0.6 times length of antennomere III (without the spine); antennomeres III-VII with apical inner spines, shortening toward VII (length of spine of antennomere III 0.2 times length of this antennomere).

Prothorax longitudinal; lateral margins with small, obtuse tubercle. Pronotum with 5 distinct tubercles (particularly the two lateroanterior ones) and small tubercle on each side, between lateroanterior tubercles and anterior margin; area between lateroanterior tubercles and margin with deep, wide transversal sulcus; central band smooth; laterals with short, sparse punctures; surface with long, sparse setae, laterally a little more abundant. Two-thirds of prosternum near procoxal cavities with coarse punctures, abundant and anastomosed, pubescent (interspersed with long, sparse setae). Elytra with moderately shallow, coarse, abundant punctures, finer, sparser on distal fourth; surface with short, sparse setae, interspersed with long setae; apex with long outer spine and sutural denticle. Metepisterna pubescent, denser at distal third. Metasternum pubescent near metepisterna, with long, sparser setae on remaining surface. Urosternites almost smooth on disk, laterally with short, abundant setae, longer, sparser on remaining surface (more abundant toward urosternite V). Femora fusiform; apex of mesofemora with spines of same length; apex of metafemora with external spine longer than inner.

Dimensions in $\mathrm{mm}$ (male). Total length 16.5; length of prothorax at center 3.1; anterior width of prothorax 2.3; posterior width of prothorax 2.4; humeral width 3.3; elytral length 11.1.

Type material. Holotype male, BrazIL, Maranhão: Bom Jardim (REBIO - Reserva Biológica do Gurupi), 02-11.IX.2010, F.L. Oliveira, J.C. Silva, J.A. Silva \& M.M. Abreu leg. (MZUSP). Etymology. Latin, igneus $=$ the color of fire, referring to the general orange color.

Remarks. Stizocera ignea sp. nov. belongs to the group of species having a spine or tubercle on lateral margins of prothorax. It differs from $S$. poeyi (Guérin-Méneville, 1838), $S$. phtisica Gounelle, 1909, and S. wagneri (Gounelle, 1913) by the absence of a yellowish spot at middle of the elytra (present in these three species). It differs from $S$. jassuara (Martins \& Napp, 1983) by the dark brown spot covering apical fourth of elytra, and dorsal surface of head, antennae, femora, tibiae and tarsi dark brown. In $S$. jassuara only the area near and on elytral spines is darkened, the head is reddish, the antennae, tibiae and tarsi are light brown and the femora are bicolor. It differs from S. suturalis (Martins \& Napp, 1992) by the pronotum orange and not pubescent, by the shiny elytra, without dark brown band along suture, and by the antennae and legs dark brown. In S. suturalis the pronotum has pubescent areas and is brown or dark brown, the elytra are opaque, with dark brown band along suture, and the antennae and legs are yellowishbrown. It differs from S. atiaia (Martins \& Napp, 1983) as follows: prothorax with small lateral tubercle; pronotum without transversal sulcus; apical fourth of elytra dark brown; and dorsal surface of head, antennae and legs dark. In S. atiaia the lateral tubercle of prothorax is large, the pronotum is transversally striated, the apical fourth of elytra is not darkened, and the head, antennae and legs are pale.

Stizocera ignea can be included in the alternative of couplet "3" from MarTins (2005):

3(2). Elytra without yellowish spot at middle; distal fourth dark brown. Brazil (Maranhão) ......................... S. ignea sp. nov.

- Elytra with yellowish spot at middle or entirely yellowish....3a

$3 a(3)$. Antennae and tibiae yellow-orange; elytra entirely yellowish or with distinct spot, but never surrounded by black line

- Antennae and tibiae black; elytra reddish, each one with central yellowish spot surrounded by black line. Cuba, Costa Rica, Panama, Venezuela, Colombia, Brazil (Amazonas, Acre, Rondônia), Bolivia .......... S. poeyi (Guérin-Méneville, 1838)

\section{Stizocera lissonota (Bates, 1870)}

Material examined. BraziL, Maranhão: Mirador (Parque Estadual Mirador, Base da Geraldina, 06³7'25"S, 4552'08"W), 1 male, 1 female, 13-19.X.2012, F.L. Oliveira, L.L.M. Santos \& L.S. Santos leg., Malaise trap; 2 females, 12-20.X.2012, F.L. Oliveira, L.S. Santos \& C.F. Barros leg., light trap.

This species was described from Brazil (Pará) and occurs in Panama, Bolivia, French Guiana, and Brazil (Pará, Rondônia, Mato Grosso, Mato Grosso do Sul, Goiás, and Minas Gerais) (Martins 2005, Monné 2014a).

\section{Stizocera tristis (Guérin-Méneville, 1844)}

Material examined. Brazil, Maranhão: Mirador (Parque Estadual Mirador, Base da Geraldina), 2 males, 17-21.II.2007, F.L. Oliveira leg., light trap.

This species was described from Bolivia and later recorded from Brazil (Rondônia, Distrito Federal, Mato Grosso, Mato Grosso do Sul, Goiás, Piauí, Paraíba, Minas Gerais, and São Paulo), Paraguay, and Argentina (ZajCIw 1965, Di Iorio 2004, Martins 2005, BeZark \& Monné 2013).

\section{Heteropsini Lacordaire, 1868}

\section{Chrysoprasis itaiuba Napp \& Martins, 1997}

Material examined. Brazil, Maranhão: Caxias (Campus UEMA, Morro do Alecrim), 1 female, 26-30.V.2010, A.S. Silva \& K.S. Lobo leg., entomologial net.

This species was described from Brazil (Amazonas and Pará) and it is also recorded from French Guiana (BezARK \& Monné 2013).

\section{Chrysoprasis variabilis Zajciw, 1958}

Material examined. Brazil, Maranhão: Caxias (Campus UEMA), female, 09.II.2011, A.A.T. Sousa \& D.W.A. Marques leg., entomologial net. 
This species was described from Brazil (Paraíba) and it is also recorded from the Brazilian states of Rio Grande do Norte, Ceará, and Pernambuco (Monné 2014a).

\section{Hexoplini Martins, 2006 Epacroplon cruciatum (Aurivillius, 1899)}

Material examined. BraziL, Maranhão: Mirador (Parque Estadual Mirador, Base da Geraldina, 06²46’37"S, 4552'08"W), 1 male, 12-20.X.2012, F.L. Oliveira, L.S. Santos \& C.F. Barros leg., light trap.

This species was described from Brazil (Rio de Janeiro) and occurs in Brazil (Piauí, Bahia, Minas Gerais, Espírito Santo, Rio de Janeiro, São Paulo, Paraná, Santa Catarina, and Rio Grande do Sul), Paraguay, and Argentina (Monné 2014a).

\section{Gnomidolon peruvianum Martins, 1960}

Material examined. BRAzIL, Maranhão: Bom Jardim (REBIO - Reserva Biológica do Gurupi; $3^{\circ} 14^{\prime} \mathrm{S}, 46^{\circ} 41^{\prime} \mathrm{W}$ ), 7 specimens (unknow sex), 02-11.IX.2010, D.W.A. Marques, E.A.S. Barbosa, J.A. Silva \& M.M. Abreu leg., Malaise trap.

This species was described and was known only from Peru (Monné 2014a). Brazil is a new country record.

\section{Hexoplon speciosum ferruginosum Martins, 1959}

Material examined. BRAZIL, Maranhão: Bom Jardim (REBIO - Reserva Biológica do Gurupi), 1 male, 2-11.IX.2010, D.W.A. Marques, E.A.S. Barbosa \& M.M. Abreu leg., bait: benzyl acetate.

This subspecies was described from Peru, Brazil (São Paulo and Paraná), and Paraguay. It is also recorded from the Brazilian state of Mato Grosso do Sul (MarTins 2006). Originally described as a distinct species, it was later considered a subspecies of $H$. speciosum Fisher, 1937 by Martins (1967). The paratypes from Peru were never formally considered as belonging to another species or subspecies.

\section{Necydalopsini Lacordaire, 1868 Ozodes malthinoides Bates, 1870}

Material examined. Brazil, Maranhão: Mirador (Parque Estadual Mirador, Base da Geraldina, 06 $\left.46^{\prime} 37^{\prime \prime S}, 45^{\circ} 52^{\prime} 08^{\prime \prime W}\right)$, 1 female, 12-20.X.2012, F.L. Oliveira, L.S. Santos \& C.F. Barros leg., light trap.

This species was described from Brazil (Amazonas). It is also recorded from Bolivia and French Guiana (MonNé 2014a).

\section{Neoibidionini Monné, 2012 Compsa multiguttata Melzer, 1935}

Material examined. BRAzIL, Maranhão: Mirador (Parque Estadual Mirador, Base da Geraldina, 06 $46^{\prime} 37^{\prime \prime}$ S, 45 $52^{\prime} 08^{\prime \prime W}$ ), 1 female, 12-20.X.2012, F.L. Oliveira, L.S. Santos \& C.F. Barros leg., light trap.
This species was described from Argentina. It occurs in Bolivia, Argentina, Brazil (Pernambuco, Bahia, Mato Grosso, Goiás, Minas Gerais, São Paulo, Santa Catarina, and Rio Grande do Sul), and Paraguay (Monné 2014a).

\section{Compsa quadriguttata (White, 1855)}

Material examined. BrAzIL, Maranhão: Bom Jardim (REBIO - Reserva Biológica do Gurupi), 2 females, 2-11.IX.2010, D.W.A. Marques, E.A.S. Barbosa \& M.M. Abreu leg., Malaise trap.

This species was described from Brazil (Pará). It occurs in Colombia, Ecuador, Peru, Bolivia, French Guiana, Brazil (Amazonas, Pará, Rondônia, Mato Grosso, Mato Grosso do Sul, Goiás, and São Paulo), and Paraguay (Monné 2014a).

\section{Compsibidion cleophile (Thomson, 1865)}

Material examined. Brazıl, Maranhão: C.N. Maranhão (REBIO - Reserva Biológica do Gurupi; 03 $14^{\prime} \mathrm{S}, 46^{\circ} 41^{\prime} \mathrm{W}$ ), 1 male, 07-15.I.2011, F.L. Oliveira \& M.M. Abreu leg., light trap.

This species was described from Brazil (without detailed locality). It occurs in Brazilian states of Bahia, Minas Gerais, Espírito Santo, Rio de Janeiro, São Paulo, Paraná, and Santa Catarina (Monné 2014a).

\section{Engyum vicinum sp. nov.}

Figs 14-17

Holotype male. Integument reddish-brown, except for: (1) outer distal portion of antennomeres III-X brownish; (2) apex of mandibles darkened; (3) posterior to humeri, yellowish-white, elliptical spot, not very conspicuous (visible under oblique light); (4) subtriangular spot between basal fourth of elytra, not reaching suture, partially reaching epipleura; (5) yellowish-white band beyond middle of elytra, curved, ascending from margin toward suture, which it does not reach; (6) basal half of elytra brownish, except for yellowish-white areas and disk of basal fourth; (7) most of femoral peduncle yellowish-white.

Dorsal surface of head fine, abundantly punctate; with long, sparse setae. Coronal suture well-marked up to approximately level of posterior margin of eye lobes. Distance between upper eye lobes 0.65 times length of scape; distance between lower eye lobes, in frontal view, 0.90 times length of scape. Antennae as long as 2.0 times elytral length, reaching elytral apex at basal fourth of antennomere IX; antennomeres finely pubescent, with long, sparse setae (decreasing toward antennal apex); antennal formula based on length of antennomere III: scape $=0.56$; pedicel $=0.14, \mathrm{IV}=0.48, \mathrm{~V}=0.68, \mathrm{VI}=0.70$, $\mathrm{VII}=0.73, \mathrm{VIII}=0.68, \mathrm{IX}=0.68, \mathrm{X}=0.70, \mathrm{XI}=0.73$.

Pronotum with basal pubescent band; remaining surface with long, sparse setae; basal and central callosities well-demarcated, anterior ones not very conspicuous. Basal half of prosternum with pubescent " $V$ "-shaped area. Lateral carina of elytra well-marked from base to distal fourth; surface with long, 
moderately abundant setae; apex with long spine at marginal angle and rounded at sutural angle. Legs with long, sparse setae; apical flaps of meso- and metafemora rounded.

Female. Antennae as long as 1.8 times elytral length, reaching elytral apex at apex of antennomere IX.

Variability. Distal half of elytra brownish; yellowish-white spot on basal fourth of elytra more conspicuous, almost fused to next spot; brownish area of elytral basal half distinctly contains elliptical spot and is fused to transversal band; integument brownish; peduncle of femora reddish-brown; elytral apex projected or with spicule at sutural angle.

Dimensions in $\mathrm{mm}$ (male/female). Total length 6.4-7.9/ 6.7-8.5; length of prothorax at center 1.3-1.7/1.4-1.8; anterior width of prothorax 0.8-1.1/1.0-1.1; posterior width of protho$\operatorname{rax} 0.8-1.1 / 0.8-1.1$; humeral width 1.2-1.5/1.2-1.6; elytral length 4.1-5.0/4.4-5,6.

Type material. Holotype male, BraziL, Maranhão: Caxias (Campus UEMA, Morro do Alecrim), 15-25.I.2009, F.L. Oliveira leg., light trap (MZUSP). Paratypes - same locality as holotype, 1 female, 15-25.I.2009, F.L. Oliveira leg., white light (UEMA); 2 males, 25-31.I.2009, F.L. Oliveira leg. (UEMA); 1 female, 2530.XII.2008, F.L. Oliveira leg., white light (MZUSP).

Etymology. Latin = vicinum $=$ near, neighbor. Allusive to similarity with Engyum ludibriosum.

Remarks. Engyum vicinum sp. nov. differs from E. ludibriosum Martins, 1970 as follows: yellowish-white band beyond middle of elytra curved and ascending from margin to suture (straight or or nearly so in E. ludibriosum); large yellowish-white spot between basal fourth and middle of elytra and with inner margin rounded (spot smaller and straight in E. ludibriosum); distance between central yellowish-white spots of elytra moderately narrow (distinctly wider in E. ludibriosum).

Engyum vicinum can be included in the alternative of couplet "9" (modified) from MarTins (2009):

9(1). Elytra orange, each one with two whitish oblique bands, one at anterior fourth and one at middle . $9 \mathrm{a}$

- Elytra with other pattern 10

$9 \mathrm{a}(9)$. Oblique area between yellowish-white spots of elytra approximately as narrow as the most distal spot. Brazil (Maranhão) Engyum vicinum sp. nov.

- Oblique area between yellowish-white spots of elytra distinctly wider than the distal spot. Brazil (Maranhão, Goiás, Bahia, Minas Gerais, São Paulo)

E. ludibriosum Martins, 1970

\section{Heterachthes ebenus Newman, 1840}

Material examined. BraziL, Maranhão: Mirador (Parque Estadual Mirador, Base da Geraldina, 06³7'25"S, 4552'08"W), 2 males, 1 female, 12-20.X.2012, F.L. Oliveira, L.S. Santos \& C.F. Barros leg., light trap.

This species was described from the United States of America (Florida). Its current distribution includes the U.S. states of New York, Ohio, Pennsylvania, District of Columbia, New Jersey, Mississippi, Alabama, Maryland, Kansas, Virginia, Arkansas, Tennessee, North Carolina, South Carolina, Texas, Florida, Georgia, Louisiana, and New Mexico, and the following additional countries: Mexico, Honduras, Guatemala, Nicaragua, Bahamas, Puerto Rico, Cuba, Colombia, Venezuela, Guyana, Suriname, Brazil (Pará, Rondônia, Mato Grosso, Goiás, Ceará, Rio Grande do Norte, Bahia, Minas Gerais, Rio de Janeiro, São Paulo, Paraná, Santa Catarina, and Rio Grande do Sul), Paraguay, Uruguay, and Argentina (MARTINs 1970,;2009; BeZARK \& Monné 2013).

\section{Heterachthes inustus Gounelle, 1909}

Material examined. BRAZIL, Maranhão: Mirador (Parque Estadual Mirador, Base da Geraldina, $06^{\circ} 37^{\prime} 25^{\prime \prime} \mathrm{S}, 45^{\circ} 52^{\prime} 08^{\prime \prime}$ ), male, 20.X.2012, F.L. Oliveira, L.S. Santos \& C.F. Barros leg., light trap.

This species was described and was known only from Brazil (Goiás) (Monné 2014a).

\section{Megapedion lefebvrei (Gounelle, 1909)}

Material examined. BraziL, Maranhão: Bom Jardim (REBIO - Reserva Biológica do Gurupi), 1 male, 1-6.XI.2010, M.M. Abreu, J.A. Silva, G.A. Reis \& E.A.S. Barbosa leg., light trap.

This species was described from Brazil (Goiás and Bahia). It is recorded from Bolivia and Brazil (Goiás, Bahia, Espírito Santo, Rio de Janeiro, São Paulo, Paraná, and Santa Catarina) (Monné 2014a).

\section{Neocompsa fefeyei Joly, 1991}

Material examined. Brazil, Maranhão: C. N. Maranhão (REBIO - Reserva Biológica do Gurupi; 03 $14^{\prime} \mathrm{S}, 46^{\circ} 41^{\prime} \mathrm{W}$ ), 1 male, 07-15.I.2011, F.L. Oliveira, M.M. Abreu \& E.A.S. Barbosa leg., light trap.

This species was described and was known only from Venezuela (Monné 2014a). Brazil is a new country record.

\section{Opsibidion albinum (Bates, 1870)}

Material examined. Brazil, Maranhão: Caxias (Campus UEMA, Morro do Alecrim), 1 female, 01-15.II.2009, F.L. Oliveira leg., white light.

This species was described from Brazil (Pará). It also occurs in Venezuela, Bolivia, and Brazil (Amazonas, Pará, and Mato Grosso) (Monné 2014a).

\section{Pygmodeon involutum (Bates, 1870)}

Material examined. BRAZIL, Maranhão: Bom Jardim (REBIO - Reserva Biológica do Gurupi), 1 female, 02-11.IX.2010, J.C. Silva, J.A. Silva \& M.M. Abreu leg., light trap.

This species was described from Brazil (Pará). It occurs in Peru, Bolivia, Guyana, French Guiana, and Brazil (Amapá, Amazonas, and Pará) (MonNé 2014a). 

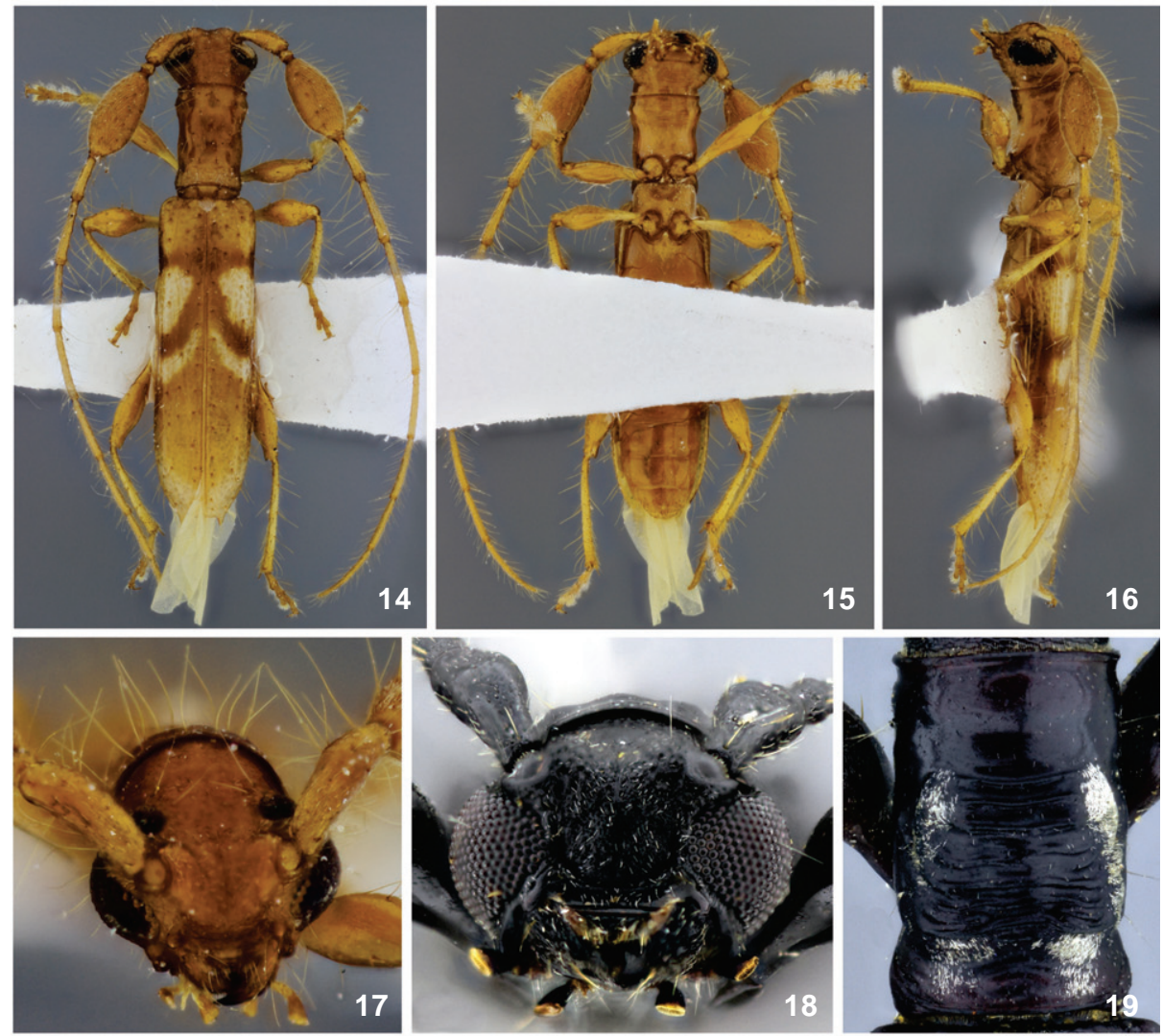

15
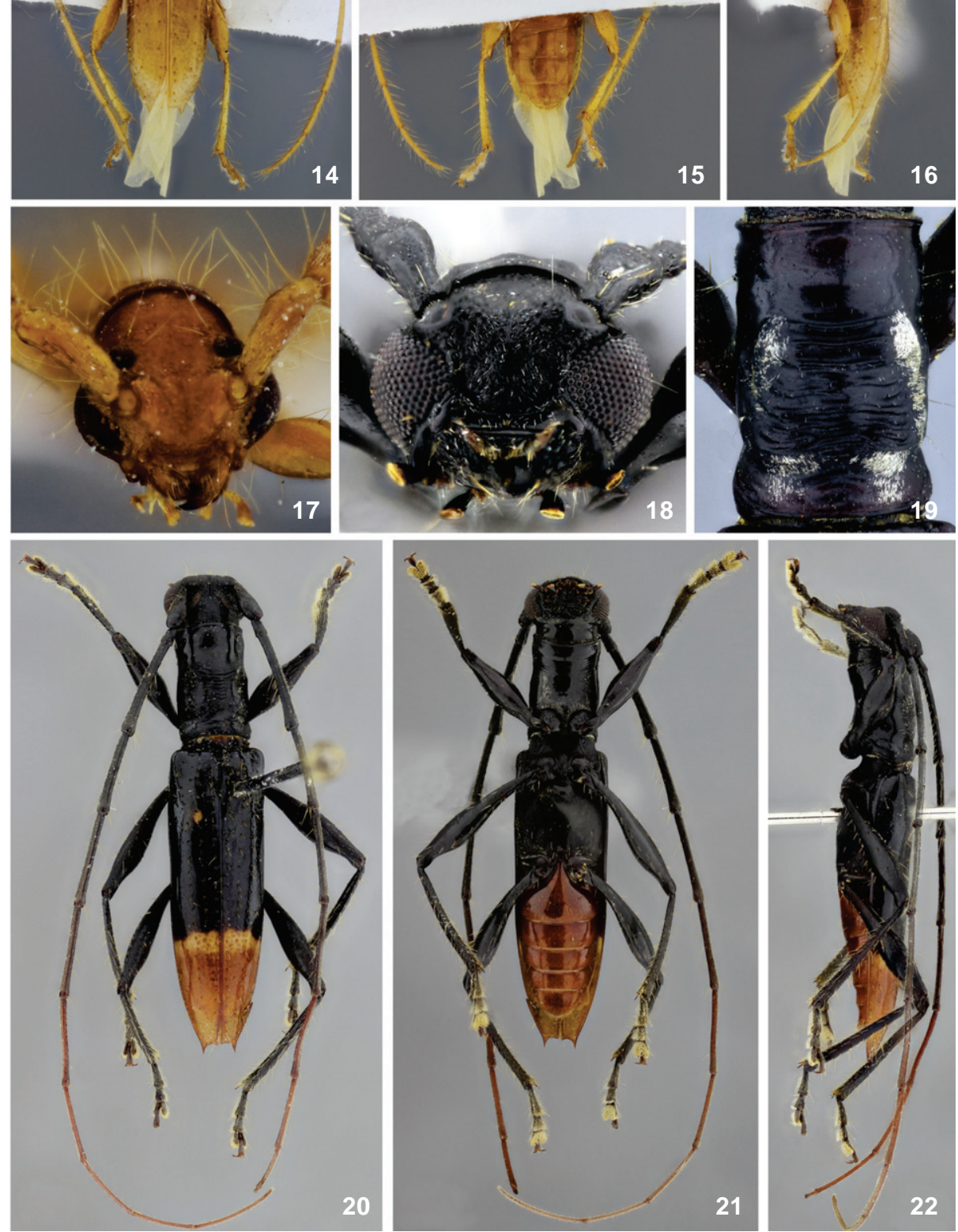

Figures 14-22. (14-17) Engyum vicinum sp. nov., holotype male: (14) dorsal view; (15) ventral view; (16) lateral view; (17) head, frontal; (18, 20-22) Thoracibidion rubripenne sp. nov., holotype male: (18) head, frontal; (20) dorsal view; (21) ventral view; (22) lateral view; (19) Thoracibidion ruficaudatum, male, pronotum. 


\section{Stenoidion c. corallinum (Bates, 1870)}

Material examined. BRAzIL, Maranhão: Bom Jardim (REBIO - Reserva Biológica do Gurupi), 1 female, 12-20.X.2012, F.L. Oliveira, L.S. Santos \& C.F. Barros leg., light trap.

This subspecies was described from Brazil (Pará) and also recorded from Peru, Bolivia, and French Guiana (Monné 2014a).

\section{Thoracibidion rubripenne sp. nov.}

Figs 18, 20-22

Holotype male. Integument black; antennomeres V-XI dark brown (gradually paler toward apical antennomeres); elytra with transverse, yellowish-white band at base of distal third, orange on remaining of this third; urosternites orange.

Frons and antennal tubercles opaque, coarse, abundantly punctate; setae very short, sparse. Area between upper eye lobes opaque, striate-punctate. Vertex shiny, shallow, moderately abundantly punctate; on each side, behind eye lobes, with one long seta. Antennal tubercles with apex projected, acute. Distance between upper eye lobes 0.3 times length of scape; distance between lower eye lobes 0.6 times length of scape. Submentum punctatestriate; setae short, moderately abundant. Antennae as long as 2.7 times elytral length, reaching elytral apex at middle of antennomere VII; antennal formula, based on length of antennomere III: scape $=0.45$, pedicel $=0.20, \mathrm{IV}=0.82, \mathrm{~V}=0.93$, $\mathrm{VI}=0.90, \mathrm{VII}=0.85, \mathrm{VIII}=0.77, \mathrm{IX}=0.77, \mathrm{X}=0.72, \mathrm{XI}=0.94$.

Pronotum with fine, transverse wrinkles between lateral callosities; pubescent band moderately narrow, from basal transverse sulcus to lateroanterior callosity; disk with long, very sparse setae. Basal half of prosternum with pubescent " $U$ "-shaped area; distal half finely, transversely grooved on distal fourth, microsculptured near head. Elytra with three rows of moderately coarse punctures, sutural row almost reaches elytral apex, intermediate row reaches yellowish band area, and lateral row reaches apical fifth; remaining surface very finely, moderately abundantly punctured; outer apical angle with long spine and sutural angle projected; setae moderately long in 3 rows from base to near apex, another, more lateral, with conspicuously sparser setae. Metasternum pubescent (more conspicuously laterally, less at center). Urosternites very finely, sparsely punctate; pubescent on laterals, with long, sparse setae on disk. Mesofemora with rounded lobe at inner and outer apices; metafemora with triangular lobe at outer and inner apices.

Female. Antennae as long as 2.2 times elytral length, reaching elytral apex at middle of antennomere VIII.

Dimensions in mm (male/female). Total length 12.6/9.6; length of prothorax at center 3.0/2.2; anterior width of prothorax 1.8/1.4; posterior width of prothorax 1.8/1.4; humeral width 2.4/1.9; elytral length 7.9/6.2.

Type material. Holotype male, BraziL, Maranhão: Caxias (Campus UEMA, Morro do Alecrim), 01-15-II.2009, F.L. Oliveira leg., white light (MZUSP). Paratypes - same locality as holotype, 1 female, 25-31.I.2009, F.L. Oliveira leg., white light (UEMA).
Etymology. Latin, ruber $=$ red; penna $=$ feather, wing Allusive to the color of the elytral apex.

Remarks. Thoracibidion rubripenne sp. nov. differs from $T$. ruficaudatum (Thomson, 1865) mainly by the pronotum with fine wrinkles (thick in T. ruficaudatum). MarTins \& GALILEO (2007) wrote the following about $T$. ruficaudatum (translated): "Pronotum with two types of wrinkles, thick, and very fine, indistinct". The specimens of T. ruficaudatum deposited at the MZUSP collection have no wrinkles on the pronotum (Fig. 19) that are thin and near each other as in the new species. In the holotype of T. rubripenne, there is a small rounded spot on basal third of left elytron. This suggests that specimens with spots on both elytra may exist and that these spots may be large.

Thoracibidion rubripenne can be included in the alternative of couplet "3" from Martins \& GaLILEo (2007):

3(2). Elytra with anterior two-thirds black and apical third reddish, separated by yellowish-white band ................ 3a

- Elytra with other color patterns ......................................... 4

3a(3). Pronotum with thick wrinkles. Venezuela, French Guiana, Peru, Brazil (Amapá, Amazonas, Pará, Rondônia) T. ruficaudatum (Thomson, 1865)

- Pronotum with fine wrinkles. Brazil (Maranhão) T. rubripenne sp. nov.

\section{Tropidion rusticum (Gounelle, 1909)}

Material examined. Brazil, Maranhão: Mirador (Parque Estadual Mirador, Base da Geraldina, $06^{\circ} 46^{\prime} 37^{\prime \prime}$, $\left.45^{\circ} 52^{\prime} 08^{\prime \prime W}\right)$, 1 female, 17-21.II.2007, F.L. Oliveira leg., light trap.

This species was described from Brazil (Goiás). It occurs in Bolivia, Brazil (Piauí, Bahia, Goiás, Mato Grosso, Mato Grosso do Sul, Minas Gerais, and São Paulo), and Paraguay (Monné 2014a).

\section{Tropidion sipolisi (Gounelle, 1909)}

Material examined. BraziL, Maranhão: Caxias (Campus UEMA, Morro do Alecrim), 3 males, 01-10.I.2010, F.L. Oliveira leg., white light.

This species was described from Brazil (Goiás). It occurs in Bolivia, Brazil (Piauí, Goiás, Bahia, Minas Gerais, Espírito Santo, Rio de Janeiro, São Paulo, and Santa Catarina), and Paraguay (Martins 1968, Monné 2014a).

\section{Tropidion zonapterum (Martins, 1962)}

Material examined. BraziL, Maranhão: Mirador (Parque Estadual Mirador, Base da Geraldina, $\left.06^{\circ} 37^{\prime} 25^{\prime \prime} \mathrm{S}, 45^{\circ} 52^{\prime} 08^{\prime \prime} \mathrm{W}\right)$, 9 males, 3 females, 12-20.X.2012, F.L. Oliveira, L.S. Santos \& C.F. Barros leg., light trap.

This species was described from Bolivia and Brazil [Mato Grosso (currently Mato Grosso do Sul), and São Paulo]. It is recorded also from the Brazilian states of Mato Grosso, Goiás, Tocantins, and Distrito Federal (Martins \& Galileo 2007, 2012). 


\section{Obriini Mulsant, 1839}

\section{Obrium trifasciatum Bosq, 1951}

Material examined. BRAzIL, Maranhão: Caxias (Campus UEMA, Morro do Alecrim), 1 male, 25-31.I.2009, F.L. Oliveira leg., white light.

This species was described from Argentina. It occurs also in Bolivia, French Guiana, Brazil (Bahia, Mato Grosso, and São Paulo), and Uruguay (MonNé 2014a).

\section{Oemini Lacordaire, 1868}

\section{Atenizus hylaeanus Martins, 1981}

Material examined. BraziL, Maranhão: Caxias (Campus UEMA, Morro do Alecrim), 1 female, 15-25.I.2009, F.L. Oliveira leg., white light.

This species was described and is known only from Brazil (Amazonas) (Bezark \& Monné 2013).

\section{Malacopterus tenellus (Fabricius, 1801)}

Material examined. Brazil, Maranhão: C.N. Maranhão (REBIO - Reserva Biológica do Gurupi; 03¹4'S, 46 $41^{\circ} \mathrm{W}$ ), 1 female, 07-15.I.2011, F.L. Oliveira \& M.M. Abreu leg., light trap.

This species was described from "America meridionali". It occurs in United States of America (Utah, Texas, California, and Arizona), Mexico, Belize, Guatemala, Honduras, Nicaragua, Panama, Cuba, Jamaica, Dominican Republic, Guadeloupe, Ecuador, Peru, Colombia, Venezuela, Bolivia, Guyana, Suriname, French Guiana, and Brazil (Amazonas, Pará, and Mato Grosso) (Martins 1997, Bezark \& Monné 2013, Monné 2014a).

\section{Methioeme brevipennis Zajciw, 1963}

Material examined. BraziL, Maranhão: Mirador (Parque

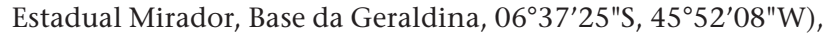
1 female, 12-20.X.2012, F.L. Oliveira, L.S. Santos \& C.F. Barros leg., light trap.

This species was described from Brazil (Amazonas) and is also recorded from the Brazilian states of Pará, Mato Grosso, Mato Grosso do Sul, and São Paulo (Monné 2014a).

\section{Neoeme bouvieri Gounelle, 1909}

Material examined. Brazil, Maranhão: Mirador (Parque Estadual Mirador, Base da Geraldina, 06 $37^{\prime} 25^{\prime \prime}$ S, 45 $52^{\prime} 08^{\prime \prime W}$ ), 1 female, 12-20.X.2012, F.L. Oliveira, L.S. Santos \& C.F. Barros leg., light trap.

This species was described from Brazil (Goiás). It occurs in Peru, Bolivia, French Guiana, and Brazil (Pará, Mato Grosso, Mato Grosso do Sul, Goiás, Minas Gerais, São Paulo, and Paraná) (Monné 2014a).

\section{Piezocerini Lacordaire, 1868}

\section{Alienosternus solitarius (Gounelle, 1909)}

Material examined. BRAzIL, Maranhão: Mirador (Parque
Estadual Mirador, Base da Geraldina, $\left.06^{\circ} 37^{\prime} 25^{\prime \prime} \mathrm{S}, 45^{\circ} 52^{\prime} 08^{\prime \prime} \mathrm{W}\right)$, 1 male, 12-20.X.2012, F.L. Oliveira, L.S. Santos \& C.F. Barros leg., light trap.

This species was described from Brazil (Goiás) and later recorded from the Brazilian states of Mato Grosso and Minas Gerais (Monné 2014a).

\section{Gorybia castanea (Gounelle, 1909)}

Material examined. BRAzIL, Maranhão: Caxias (Campus UEMA, Morro do Alecrim), 1 male, 1 female, 25-30.XII.2009, F.L. Oliveira leg., white light.

This species was described from Brazil (Goiás) and later recorded from the Brazilian states of Mato Grosso, Mato Grosso do Sul, Piauí, Minas Gerais, and São Paulo (Martins 2003, Monné 2014a).

\section{Gorybia rugosa Martins, 1976}

Material examined. BRAzIL, Maranhão: Caxias (Campus UEMA, Morro do Alecrim), 1 male, 13-14.XII.2010, F.L. Oliveira \& M.M. Abreu leg., entomological net.

This species was described and known only from Brazil (Bahia) (Monné 2014a).

\section{Hemilissa gummosa (Perty, 1832)}

Material examined. Brazil, Maranhão: Mirador (Parque Estadual Mirador, Base da Geraldina, 06 $37^{\prime} 25^{\prime \prime}$, 45 $45^{\circ} 52^{\prime} 08^{\prime \prime} \mathrm{W}$ ), 3 females, 12-20.X.2012, F.L. Oliveira, L.S. Santos \& C.F. Barros leg., light trap.

This species was described from Brazil (Rio de Janeiro). It is recorded from Bolivia, Brazil (Paraíba, Rio Grande do Norte, Pernambuco, Bahia, Goiás, Mato Grosso, Minas Gerais, Espírito Santo, Rio de Janeiro, São Paulo, Paraná, Santa Catarina, and Rio Grande do Sul), Paraguay, and Argentina (Martins 2003; WAPpes et al. 2006; Monné 2014a).

\section{Hemilissa opaca Martins, 1976}

Material examined. BraziL, Maranhão: Mirador (Parque Estadual Mirador, Base da Geraldina, 06 37'25"S, 4552'08"W), 1 male, 12-20.X.2012, F.L. Oliveira, L.S. Santos \& C.F. Barros leg., light trap.

This species was described from Venezuela, Guyana, French Guiana, and Brazil (Amazonas and Pará) and occurs also in the Brazilian state of Roraima and from Colombia (MARtins 2003; BeZark \& Monné 2013).

\section{Rhinotragini Thomson, 1861 \\ Acyphoderes crinita (Klug, 1825)}

Material examined. BraziL, Maranhão: Bom Jardim (REBIO - Reserva Biológica do Gurupi), 1 male, 01-06.XI.2010, M.M. Abreu, J.A. Silva, G.A. Reis \& E.A.S. Barbosa leg., Malaise trap.

This species was described from Brazil, and additional locality details were not included in the label. It occurs in Bra- 
zil (Espírito Santo, Rio de Janeiro, São Paulo, Paraná, Santa Catarina, and Rio Grande do Sul), Bolivia, Paraguay, and Argentina (Monné 2014a).

\section{Agaone notabilis (White, 1855)}

Material examined. BRAzIL, Maranhão: Bom Jardim (REBIO - Reserva Biológica do Gurupi), 1-6.XI.2010, 1 female, F.L. Oliveira, E.A.S. Barbosa \& G.A. Reis leg., flight intercept trap; 1 male, 02-11.IX.2010, D.W.A. Marques, E.A.S. Barbosa, J.A. Silva $\&$ M.M. Abreu leg., Malaise trap.

This species was described from Brazil (Pará). It occurs in Ecuador, Peru, Suriname, Guyana, French Guiana, and Brazil (Amazonas, Rondônia, Pará, and Mato Grosso) (BezArK et al. 2011; SouzA $\&$ SiLva 2012; MonnÉ 2014a). The records from the states of eastern Brazil correspond to A. punctilla Martins \& Santos-Silva, 2010.

\section{Optomerus bispeculifer (White, 1855)}

Material examined. BrAzIL, Maranhão: C. N. Maranhão (REBIO - Reserva Biológica do Gurupi; 03¹4'S, 46²41'W), 1 female, 0715.I.2011, F.L. Oliveira, M.M. Abreu \& E.A.S. Barbosa leg., light trap.

This species was described from Brazil (Pará). It is recorded also from Panama, Guyana, French Guiana, and the Brazilian state of Mato Grosso (Monné 2014a).

\section{Odontocera simplex White, 1855}

Material examined. BraziL, Maranhão: Bom Jardim (REBIO - Reserva Biológica do Gurupi), 1 female, 01-06.XI.2010, F.L. Oliveira, D.W.A. Marques \& E.A.S. Barbosa leg., Malaise trap.

This species was described from Brazil (Pará). It is recorded also from Bolivia, French Guiana, and from the Brazilian states of Amazonas and Rondônia (MonNé 2014a).

\section{Pandrosos phtisicus (Klug, 1825)}

Material examined. BRAzIL, Maranhão: C. N. Maranhão (REBIO - Reserva Biológica do Gurupi; 03¹4'S, 46² $41^{\prime} \mathrm{W}$ ), 1 female, 0715.I.2011, F.L. Oliveira \& D.W.A. Marques leg., flight intercept trap.

This species was described from Brazil (Bahia). It occurs in Costa Rica, Panama, and Brazil (Amazonas, Pará, Rondônia, Goiás, Mato Grosso, and Bahia) (Monné 2014a).

\section{Pandrosos proximus Mermudes \& Napp, 2009}

Material examined. BRAzIL, Maranhão: C.N. Maranhão (REBIO - Reserva Biológica do Gurupi; 03¹4'S, 46²41'W), 1 male, 0715.I.2011, F.L. Oliveira \& D.W.A. Marques leg., flight intercept trap.

This species was described and was known only from Brazil (Mato Grosso) (Monné 2014a).

\section{Tomopterus consobrinus Gounelle, 1911}

Material examined. BRAzIL, Maranhão: Bom Jardim (REBIO - Reserva Biológica do Gurupi), 1 male, 1 female, 01-06.XI.2010, F.L. Oliveira, D.W.A. Marques \& E.A.S. Barbosa leg., Malaise trap.
This species was described from Brazil (Goiás) and also recorded from the Brazilian sates of Pará, Rondônia, Mato Grosso, and Espírito Santo. It also occurs in Trinidad and Tobago, French Guiana, Peru, and Bolivia (Monné 2014a).

\section{Tomopterus obliquus Bates, 1870}

Material examined. BRAzIL, Maranhão: Bom Jardim (REBIO - Reserva Biológica do Gurupi), 1 male, 2 females, 0211.IX.2010, D.W.A. Marques, E.A.S. Barbosa, J.A. Silva \& M.M. Abreu leg., Malaise trap; 14 males, 36 females, 01-06.XI.2010, F.L. Oliveira, D.W.A. Marques \& E.A.S. Barbosa leg., Malaise trap.

This species was described from Brazil (Pará) and occurs in the states of Amazonas, Rondônia, Mato Grosso, Goiás, Bahia, Espírito Santo, and Rio de Janeiro. It is also recorded from Peru, French Guiana, Paraguay, and Argentina (Bezark et al. 2013).

\section{Tomopterus servillei Magno, 1995}

Material examined. BRAzIL, Maranhão: Bom Jardim (REBIO - Reserva Biológica do Gurupi), 1 female, 01-06.XI.2010, F.L. Oliveira, D.W.A. Marques \& E.A.S. Barbosa leg., Malaise trap.

This species was described from Brazil (Pará) and recorded from French Guiana (MonNé 2014a).

\section{Tomopterus similis Fisher, 1930}

Material examined. BRAZIL, Maranhão: Bom Jardim (REBIO - Reserva Biológica do Gurupi), 1 male, 02-11.IX.2010, D.W.A. Marques, E.A.S. Barbosa, J.A. Silva \& M.M. Abreu leg., Malaise trap; 25 males, 20 females, 01-06.XI.2010, F.L. Oliveira, D.W.A. Marques \& E.A.S. Barbosa leg., Malaise trap.

This species was described from Bolivia and recorded from French Guiana and from Brazil (Amazonas and Pará) (Monné 2014a).

\section{Torneutini Thomson, 1861}

\section{Gnathopraxithea sarryi Campos-Seabra \& Tavakilian, 1986}

Material examined. BraziL, Maranhão: C.N. Maranhão (REBIO - Reserva Biológica do Gurupi; 03 ${ }^{\circ} 14^{\prime} \mathrm{S}, 46^{\circ} 41^{\prime} \mathrm{W}$ ), 1 female, 7-15.I.2011, F.L. Oliveira, M.M. Abreu \& E.A.S. Barbosa leg., light trap.

This species was described from French Guiana and Brazil (Pará and Amapá). It occurs in Ecuador, Peru, Venezuela, Bolivia, and French Guiana (Tavakilian 1996; Demez \& Touroult 2012; Monné 2014a).

\section{Praxithea borgmeieri Lane, 1938}

Material examined. BRAzIL, Maranhão: Caxias (Res. Eleg. Inhamum, Povoado Coités, $\left.04^{\circ} 54^{\prime} 43^{\prime \prime} S, 43^{\circ} 25^{\prime} 30^{\prime \prime} \mathrm{W}\right), 1$ female, 25-26.XI.2011, M. K. A. Santos, C. M. S. Silva \& A. A. Santos 
leg., light trap; Mirador (Parque Estadual Mirador, Base da Geraldina, 06 $\left.37^{\prime} 25^{\prime \prime S}, 45^{\circ} 52^{\prime} 08^{\prime \prime} \mathrm{W}\right), 1$ female, 12-20.X.2012, F.L. Oliveira, L.S. Santos \& C.F. Barros leg., light trap.

This species was described from Brazil (Goiás). It is recorded from Ecuador, Venezuela, French Guiana, and Brazil (Goiás, Mato Grosso, Mato Grosso do Sul, and Minas Gerais) (Monné 2014a).

\section{Trachyderini Dupont, 1836}

\section{Athetesis angulicollis (Zajciw, 1961)}

Material examined. Brazil, Maranhão: C.N. Maranhão

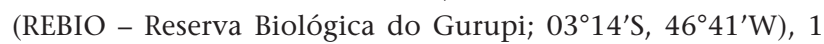
male, 07-15.I.2011, F.L. Oliveira, M.M. Abreu \& E.A.S. Barbosa leg., light trap.

This species was described from Brazil (Pará) and also recorded from Suriname and French Guiana (MonNé 2014a).

\section{Unachlorus viridis Martins \& Galileo, 2008}

Material examined. BRAzIL, Maranhão: Bom Jardim (REBIO - Reserva Biológica do Gurupi), 1 male, 1 female, 2-11.IX.2010, F.L. Oliveira, J.C. Silva, J.A. Silva \& M.M. Abreu leg., light trap.

This species was described and was known only from Brazil (Pará) (Monné 2014a).

\section{Lamiinae Latreille, 1825}

\section{Acanthocinini Blanchard, 1845}

Xylergates picturatus Lane, 1957

Material examined. BRAzIL, Maranhão: Bom Jardim (REBIO - Reserva Biológica do Gurupi), 1 male, 2-11.IX.2010, F.L. Oliveira, J.C. Silva \& D.W.A. Marques leg.

This species was described from Peru and Brazil (Amazonas) and occurs in Ecuador, Colombia, Bolivia, and from the Brazilian state of Rondônia (Bezark \& Monné 2013).

\section{Acanthoderini Thomson, 1860}

\section{Aegoschema moniliferum (White, 1855)}

Material examined. Brazil, Maranhão: Mirador (Parque Estadual Mirador, Base da Geraldina, 06 $37^{\circ} 25^{\prime \prime S}, 45^{\circ} 52^{\prime} 08^{\prime \prime W}$ ), 1 female, 13-19.X.2012, F.L. Oliveira, L.L.M. Santos \& L.S. Santos leg., Malaise trap; Bom Jardim (REBIO - Reserva Biológica do Gurupi), 2 females, 2-11.IX.2010, F.L. Oliveira, J.C. Silva, J.A. Silva \& M.M. Abreu leg., light trap.

This species was described from Brazil (Pará). It occurs in Bolivia, French Guiana, Peru, and Brazil (Amazonas, Pará, Rondônia, Goiás, and Mato Grosso) (WAPpes et al. 2006; Monné \& Mermudes 2007). Bose \& Ruffinelli (1951) recorded this species from Uruguay, ZajcIw (1972) from Rio de Janeiro, and ZAJcIW (1974) from Espírito Santo. Later, Monné (1994, 2005, 2014b), Monné \& Giesbert (1994), Monné \& Mermudes (2007), and Bezark $\&$ MonNé (2013) did not nomentioned and/or formalized the exclusion of occurrence from Uruguay and for the states of southeastern Brazil.

\section{Myoxinus pictus (Erichson, 1847)}

Material examined. BRAziL, Maranhão: C. N. Maranhão (REBIO - Reserva Biológica do Gurupi), 1 male, 01-06.III.2011, F.L. Oliveira, M.M. Abreu \& J.A. Silva leg., light trap.

This species was described from Peru and later it was recorded from Mexico, Guatemala, Honduras, Nicaragua, Costa Rica, Panama, Ecuador, Peru, Bolivia, French Guiana, Brazil (Amazonas, Pará, and Rio de Janeiro), and Paraguay (Villiers 1971; Di Iorio 2004; Bezark \& Monné 2013; Monné 2014b).

\section{Nesozineus bucki (Breuning, 1954)}

Material examined. BRAzIL, Maranhão: Caxias (Campus UEMA, Morro do Alecrim), 1 male, 1-10.I.2010, F.L. Oliveira leg., white light

This species was described from Brazil (Rio Grande do Sul). It occurs in Mexico, Honduras, Costa Rica, Panama, Venezuela, Bolivia, Argentina, Paraguay, and Brazil (Mato Grosso do Sul, Alagoas, Paraíba, Sergipe, Minas Gerais, Espírito Santo, Rio de Janeiro, and Paraná) (Zajciw 1965, Di Iorio 2004, Bezark \& Monné 2013, Monné 2014b).

\section{Nesozineus clarkei Galileo \& Martins, 2007}

Material examined. BrazIL, Maranhão: Bom Jardim (REBIO - Reserva Biológica do Gurupi), 1 male, 05-15.VI.2010, J.C. Silva, J.A. Silva, A.A. Santos \& T.T.A. Silva leg., light trap.

This species was described from Bolivia and also recorded from Peru (Monné 2014b). Brazil is a new country record.

\section{Nesozineus griseolus Hoffmann, 1984}

Material examined. BraziL, Maranhão: Caxias (Campus UEMA, Morro do Alecrim), 1 female, 1-15.II.2009, F.L. Oliveira leg., white light.

This species was described from Brazil (Paraíba). It occurs in Argentina (Monné 2014b).

\section{Nesozineus simile Galileo \& Martins, 2006}

Material examined. Brazil, Maranhão: Caxias (Campus UEMA, Morro do Alecrim), 1 female, 1 male, 15-25.I.2009, F.L. Oliveira leg., white light; 1 male, 13-14.II.2010, F.L. Oliveira leg., entomological net.

This species was described and recorded only from Bolivia (Monné 2014b). Brazil is a new country record.

\section{Oreodera basiradiata Tippmann, 1960}

Material examined. BRAzIL, Maranhão: Bom Jardim (REBIO - Reserva Biológica do Gurupi), 1 male, 2-11.IX.2010, F.L. Oliveira, J.C. Silva \& D.W.A. Marques leg., light trap. 
This species was described from Brazil (Amapá). It is recorded from French Guiana and Brazil (Amapá, Amazonas, Pará, Mato Grosso, Bahia, and Espírito Santo) (Monné 2014b).

\section{Psapharochrus nigricans (Lameere, 1884)}

Material examined. BraziL, Maranhão: Caxias (Três Corações, zona urbana), 1 female, 13.X.2009, F.L. Oliveira leg.; Mirador (Parque Estadual Mirador, Base da Geraldina, 06³7'25"S, $\left.45^{\circ} 06^{\prime} 34^{\prime \prime W}\right), 1$ female, 21-25.VIII.2006, F.L. Oliveira leg., light trap.

This species was described from Venezuela. It is recorded from Guatemala, Honduras, Nicaragua, Costa Rica, Panama, Colombia, Bolivia, Venezuela, French Guiana, Brazil (Amazonas, Roraima, Rondônia, Mato Grosso, Minas Gerais, Espírito Santo, Rio de Janeiro, São Paulo, Paraná, Santa Catarina, and Rio Grande do Sul), Uruguay, Paraguay, and Argentina (Viana 1972, Monné et al. 2012, Monné 2014b).

\section{Steirastoma coenosum Bates, 1862}

Material examined. BRAzIL, Maranhão: Bom Jardim (REBIO Reserva Biológica do Gurupi), 1 female, 2-11.IX.2010, D.W.A. Marques, E.A.S. Barbosa, J.A. Silva \& M.M. Abreu leg., Malaise trap; 1 female, 2-11.IX.2010, F.L. Oliveira, J.C. Silva \& D.W.A. Marques leg.

This species was described from Brazil (Pará) and is also recorded from Costa Rica, Panama, Colombia, Ecuador, and Bolivia (Gilmour 1965; Bezark \& Monné 2013; Monné 2014b).

\section{Steirastoma genisspinum Schwarzer, 1923}

Material examined. BRAzIL, Maranhão: C. N. Maranhão (REBIO - Reserva Biológica do Gurupi; 03ํำ's, 46 $41^{\prime} \mathrm{W}$ ), 3 females, 07-15.I.2011, F.L. Oliveira, M.M. Abreu \& E.A.S. Barbosa leg., light trap.

This species was described from Brazil (Mato Grosso). It occurs in Ecuador, Bolivia, French Guiana, and Brazil (Amazonas, Pará, Mato Grosso, and Mato Grosso do Sul) (MonNÉ 2014b).

\section{Aerenicini Lacordaire, 1872}

\section{Hydraschema obliquevittata (Lane, 1966)}

Material examined. BraziL, Maranhão: Mirador (Parque Estadual Mirador, Base da Geraldina, 06³7'25"S, 4552'08"W), 1 male, 12-20.X.2012, F.L. Oliveira, L.S. Santos \& C.F. Barros leg., light trap.

This species was described from Brazil (Rio de Janeiro and Santa Catarina). It occurs in Bolivia, French Guiana, and Brazil (Minas Gerais, Rio de Janeiro, São Paulo, Santa Catarina, and Rio Grande do Sul) (Martins \& Galileo 1998; Monné 2014b).

\section{Recchia hirticornis (Klug, 1825)}

Material examined. BraziL, Maranhão: C. N. Maranhão (REBIO - Reserva Biológica do Gurupi; 03ํำ'S, 46 $41^{\circ} \mathrm{W}$ ), 1 female, 07-15.I.2011, F.L. Oliveira, M.M. Abreu \& E.A.S. Barbosa leg., light trap.
This species was described from Brazil, without detailed locality. It is recorded from Venezuela, Bolivia, French Guiana, Brazil (Goiás, Mato Grosso, Mato Grosso do Sul, Pernambuco, Minas Gerais, Espírito Santo, Rio de Janeiro, São Paulo, Paraná, Santa Catarina, and Rio Grande do Sul), Paraguay, Uruguay, and Argentina (MonNé 2014b).

\section{Recchia parvula (Lane, 1938)}

Material examined. BrAzIL, Maranhão: C. N. Maranhão (REBIO

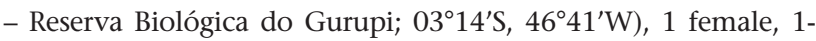
6.III.2011, F.L. Oliveira, M.M. Abreu \& J.A. Silva leg., light trap.

This species was described from Brazil (Goiás). It occurs in Bolivia, Brazil (Goiás, Distrito Federal, Mato Grosso, Mato Grosso do Sul, Minas Gerais, Rio de Janeiro, São Paulo, and Paraná), and Paraguay (Monné 1995, 2014b).

\section{Agapanthiini Mulsant, 1839} Hippopsis pubiventris Galileo \& Martins, 1988

Material examined. Brazil, Maranhão: Mirador (Parque Estadual Mirador, Base da Geraldina, 06 $37^{\prime} 25^{\prime \prime}$ S, 45 $52^{\circ} 08^{\prime \prime W}$ ), 1 female, 30.IX.2007, F.L. Oliveira, L.S. Santos \& C.F. Barros leg., Malaise trap; Caxias (Campus UEMA, Morro do Alecrim), 1 female, 10-25.IV.2009, F.L. Oliveira leg., white light; 1 female, 10-20.II.2010, F.L. Oliveira leg., white light.

This species was described from Peru and Brazil (Acre, Rio de Janeiro, São Paulo, and Santa Catarina). It is also recorded from Bolivia (Monné 2014b).

\section{Trichohippopsis exilis Galileo \& Martins, 2006}

Material examined. Brazil, Maranhão: Caxias (Campus UEMA, Morro do Alecrim), 1 male, 25.I.2012, F.L. Oliveira leg.

This species was described and from Bolivia and was only known from there (Monné 2014b). Brazil is a new country record.

\section{Anisocerini Thomson, 1860}

\section{Onychocerus concentricus Bates, 1862}

Material examined. Brazil, Maranhão: C. N. Maranhão (REBIO - Reserva Biológica do Gurupi; 0314'01"S, 46²0’52"W), 3 males, 01-6.III.2011, F.L. Oliveira, M.M. Abreu \& J.A. Silva leg., light trap; 1 female, 1-5.VII.2011, M.M. Abreu \& J.A. Silva leg., light trap.

This species was described from Brazil (Pará) and occurs in Ecuador, Peru, French Guiana, and Brazil (Amazonas, Pará, Rondônia, and Mato Grosso) (Júlio \& Monné 2001, Demez \& Touroult 2012, MonNé 2014b).

\section{Apomecynini Thomson, 1860 Adetus marmoratus Breuning, 1942}

Material examined. BRAzIL, Maranhão: Mirador (Parque Estadual Mirador, Base da Geraldina, $\left.06^{\circ} 37^{\prime} 25^{\prime \prime} S, 45^{\circ} 52^{\prime} 08^{\prime \prime W}\right)$, 
1 male, 2 females, 12-20.X.2012, F.L. Oliveira, L.S. Santos \& C.F. Barros leg., light trap.

This species was described from Brazil (Goiás) and also recorded from the Brazilian states of Minas Gerais and São Paulo and from Bolivia (Monné 2014b).

\section{Bebelis occulta (Bates, 1866)}

Material examined. BraziL, Maranhão: Coelho Neto (urban perimeter), 1 male, 20.II.2011, D.W.A. Marques leg.

This species was described from Brazil (Pará) and recorded also from Bolivia (MonNé 2014b).

\section{Colobotheini Thomson, 1860 Colobothea hirtipes (De Geer, 1775)}

Material examined. BraziL, Maranhão: C.N. Maranhão (REBIO - Reserva Biológica do Gurupi; 03ำ $14^{\prime} \mathrm{S}, 46^{\circ} 41^{\prime} \mathrm{W}$ ), 4 males, 07-15.I.2011, F.L. Oliveira, M.M. Abreu \& E.A.S. Barbosa leg., light trap; Bom Jardim (REBIO - Reserva Biológica do Gurupi), 1 female, 5-15.X.2010, F.L. Oliveira, J.C. Silva \& D.W.A. Marques leg., entomological net; 7 males, 4 females, 211.XI.2010, F.L. Oliveira, J.C. Silva \& D.W.A. Marques leg.

This species was described from "Indes". Fabricius (1793) recorded this species, from the American continent, as Saperda lineata Fabricius, 1793. ERICHSON (1848) was the first to register Colobothea hirtipes for a locality from America (French Guiana).It occurs in Trinidad and Tobago, Peru, Bolivia, Suriname, French Guiana, and Brazil (Amapá, Amazonas, Pará, Mato Grosso, and Brazil) (Aurivillius 1923; Monné 2014b). Buck (1959) recorded C. hirtipes from the Brazilian state of São Paulo. This record have been omitted in the catalogues (e.g., Monné 2014b). It is possible that the specimen identified as $C$. hirtipes does not belong to this species.

\section{Hilobothea latevittata (Bates, 1865)}

Material examined. BRAzIL, Maranhão: Bom Jardim (REBIO - Reserva Biológica do Gurupi), 1 female, 2-11.IX.2010, D.W.A. Marques, E.A.S. Barbosa, J.A. Silva \& M.M. Abreu leg., Malaise trap; 1 male, F.L. Oliveira, J.C. Silva \& D.W.A. Marques leg.

This species was described from Brazil (Amazonas and Pará). It occurs in Ecuador, Suriname, French Guiana, and from the Brazilian state of Amapá (Monné \& Martins 1979; Monné 2014b).

\section{Desmiphorini Thomson, 1860 Cicuiara striata (Bates, 1866)}

Material examined. Brazil, Maranhão: Caxias (Campus UEMA, Morro do Alecrim), 1 male, 1 female, 1-10.I.2010, F.L. Oliveira leg., white light; 1 male, 2 females, 13-14.XII.2010, F.L. Oliveira \& M.M. Abreu leg., entomological net.

This species was described from Brazil (Pará) and recorded from Venezuela, Bolivia, and Brazil (Amazonas, Pará, Mato Grosso do Sul, Goiás, and Minas Gerais) (Monné 2014b).

\section{Desmiphora (Desmiphora) fasciculata (Olivier, 1792)}

Material examined. Brazil, Maranhão: C. N. Maranhão

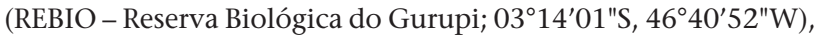
1 male, 01-05.VII.2011, F.L. Oliveira \& D.W.A. Marques leg., light trap.

This species was described from French Guiana and also known from Mexico, Guatemala, Nicaragua, Costa Rica, Panama, Colombia, Ecuador, Peru, Bolivia, French Guiana, and Brazil (Amazonas, Mato Grosso, Goiás, and Espírito Santo) (Monné 1994; Maes et al. 1994; Galileo \& Martins 2003; TavaKilian \& Néouze 2004; Monné 2014b).

\section{Monochamini Gistel, 1848}

Taeniotes pulverulentus (Olivier, 1790)

Material examined. BraziL, Maranhão: Bom Jardim (REBIO - Reserva Biológica do Gurupi), 1 male, 1 female, 1-5.I.2011, M.M. Abreu, E.A.S. Barbosa \& A.A. Santos leg., light trap.

This species was described from Antilhas, French Guiana, and Suriname. Martins \& SANTos-Silva (2012) provided the following comment: "Indeed, based on the numerous problems of identification of the species involved (T. pulverulentus and $T$. farinosus sensu auctorum, and other similar species), it is impossible to know without examination of all specimens mentioned in the literature what effectively is the geographical distribution of T. pulverulentus". Also according to Martins \& SANTOSSilva (2012), the known geographical distribution of $T$. pulverulentus is as follows: Costa Rica, Panama, Martinica, Guadalupe, Colombia, Ecuador, Peru, Bolivia, Guyana, Suriname, French Guiana, Argentina, Paraguay, and Brazil (Rio de Janeiro, Amazonas, Pernambuco, Rio Grande do Sul, Espírito Santo, São Paulo, and Bahia). Citations such as those of CHEMSAK et al. (1992) ["CAmer, SAmer, Indias Occidentales"] are very generic and speculative, without formal record of the species for several countries in Central America, Antilles, and South America. In Brazil, formal records are only available for a few states.

\section{Onciderini Thomson, 1860}

$$
\text { Lydipta conspersa (Aurivillius, 1922) }
$$

Material examined. BRAzIL, Maranhão: Caxias (Campus UEMA, Morro do Alecrim), 1 male, 15-25.I.2009, F.L. Oliveira leg., white light.

This species was described from Brazil (São Paulo). It occurs in Peru, Bolivia, Brazil (Rondônia, Goiás, Mato Grosso, Rio de Janeiro, and São Paulo), and Paraguay (Monné 2014b).

\section{Oncideres laceyi Dillon \& Dillon, 1949}

Material examined. BraziL, Maranhão: Mirador (Parque Estadual Mirador, Base da Geraldina), 1 female, 7-14.V.2010, C.G. Almeida \& M.M. Abreu leg., light trap.

This species was described and known only from Peru (Monné 2014b). Brazil is a new country record. 


\section{Oncideres satyra Bates, 1865}

Material examined. BRAZIL, Maranhão: C. N. Maranhão (REBIO - Reserva Biológica do Gurupi; 03¹4'S, 46²41'W), 3 females, 16.III.2011, F.L. Oliveira, M.M. Abreu \& J.A. Silva leg., light trap.

This species was described from Brazil (Pará). It occurs in Peru, Venezuela, Bolivia, Guyana, French Guiana, and Brazil (Amazonas, Rondônia, and Pará) (Monné 2014b).

\section{Peritrox marcelae Nearns \& Tavakilian, 2012}

Material examined. Brazil, Maranhão: C.N. Maranhão

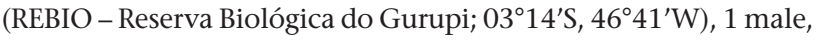
1-6.III.2011, F.L. Oliveira, M.M. Abreu \& J.A. Silva leg., light trap.

This species was described from French Guiana and also recorded from Brazil (Mato Grosso) (MonNé 2014b).

\section{Peritrox nigromaculata Aurivillius, 1920}

Material examined. BraziL, Maranhão: Caxias (Res. Eleg. Inhamum, Povoado Coités, $\left.04^{\circ} 54^{\prime} 41^{\prime \prime} \mathrm{S}, 43^{\circ} 25^{\prime} 28^{\prime \prime} \mathrm{W}\right), 1$ male, 27-29.V.2011, L.L.L. Santos \& D.W.A. Marques leg., light trap.

This species was described from Brazil (Espírito Santo) and Paraguay. It occurs in Bolivia, Argentina, and from the Brazilian states of Espírito Santo, Rio de Janeiro, and São Paulo (Viana 1972; BeZark \& Monné 2013).

\section{Polyrhaphidini Thomson, 1860 Polyrhaphis ju sp. nov.}

Figs 23-26

Holotype female. Body depressed. Integument black. Head in dorsal view almost as long as prothorax; moderately elongate behind eye. Frons slightly flattened; with coarse, sparse punctures along central band, concentrated near eyes and base of antennal tubercles; pubescence ochreous, very short, distinctly longer on narrow band from base of antennal tubercles to near lower border of lower eye lobes, from where it enlarges toward clypeus.

Vertex with pubescence concolorous with frons, not obliterating integument in some areas, forming irregular spots in others; punctures coarse, sparse, absent on triangular central area near prothorax. Clypeus narrow, with median longitudinal sulcus; pubescence ochreous, sparse. Labrum flat on basal half, conspicuously inclined on distal half; pubescence of basal half abundant, ochreous; central region of inclined distal half subglabrous. Distance between upper eye lobes 0.4 times length of scape; distance between lower eye lobes 0.7 times length of scape. Mandibles longitudinally ridged on basal half. Length of frontal portion of genae 0.8 times width of inferior ocular lobe. Antennae 1.7 times elytral length, reaching elytral apex at base of antennomere VIII; antennomeres with ochreous pubescence, less conspicuous on distal antennomeres.

Conical protuberances of pronotum distinctly elevated; callosities on basal half of disk conspicuous, particularly me- dian one; disk of laterobasal callosities with large, glabrous, elliptical area; lateral tubercles large, ending in long spine, approximately as long as half length of prothorax; disk coarsely, deeply, moderately abundantly punctate between callosities and conical protuberances, confluent at base of lateral tubercles; ochreous pubescence partially obliterating integument, more dense, yellowish-white laterally and above lateral tubercles. Scutellum with ochreous pubescence, except for narrow, glabrous longitudinal band from base to distal third.

Elytra almost parallel at basal two-thirds; longitudinal carina on basal gibbosities, low, with series of small, glabrous, shiny tubercles; area marginal to suture with tubercles moderately large, shiny up to distal third; area on gibbosities and between them and lateral carinae very coarsely punctate, with small, shiny tubercles; area between lateral carinae and epipleura coarsely, deeply, abundantly punctate, with small, shiny tubercles; lateral carina low, curved beside central gibbosity, straight and oblique up to approximately middle of elytron, where it disappears; area between lateral carina and suture with row of coarse, deep punctures, preceded by shiny, small tubercles and punctures, not in rows, preceded by small, shiny tubercles, between row of punctures and suture (more abundant near central gibbosity); apical fourth coarsely punctate near suture; humeri protruding; outer apical angle projected and sutural angle rounded; pubescence ochreous, not obliterating integument, intercalated with yellowish-white pubescent areas. Pubescence of ventral portion and legs ochreous.

Variability (paratype female): Pubescence on vertex with yellowish-white areas; antennae 1.9 times elytral length; pubescence of antennomeres denser on basal half, forming ring (particularly on antennomeres III and IV); area around elytral suture with tubercles only on basal half.

Dimensions in mm (female). Total length 19.7-24.5; length of prothorax at center 3.4-4.4; anterior width of prothorax 4.6-5.8; posterior width of prothorax 4.4-5.6; humeral width 7.3-10.0; elytral length 15.0-18.9. The larger dimensions are those of the holotype.

Type material. Holotype and paratype female, BRAzIL, Maranhão: Mirador (Parque Estadual Mirador, Base da Geraldina, $06^{\circ} 46^{\prime} 37^{\prime \prime}$ S, $\left.45^{\circ} 52^{\prime} 08^{\prime \prime} \mathrm{W}\right)$, 12-20.X.2012, F.L. Oliveira, L.S. Santos \& C.F. Barros leg., light trap.

Etymology. Tupi, jû = spine; name in apposition, not Latinized. Allusive to the lateral tubercles of the prothorax.

Remarks. Polyrhaphis ju sp. nov. differs from P. angustata Buquet, 1853 as follows: central-basal callosity of pronotum protruding (absent or almost so in $P$. angustata); punctures of pronotum sparser (very abundant in P. angustata); elytral tubercles larger and more abundant (conspicuously smaller and less abundant in P. angustata); glabrous area on each side of basal third of pronotum wider and more defined (narrower and less delimited in $P$. angustata); distal fifth of elytra more uniformly rounded on disk, without depression between lateral margin and suture (flatter on disk and with conspicuous 

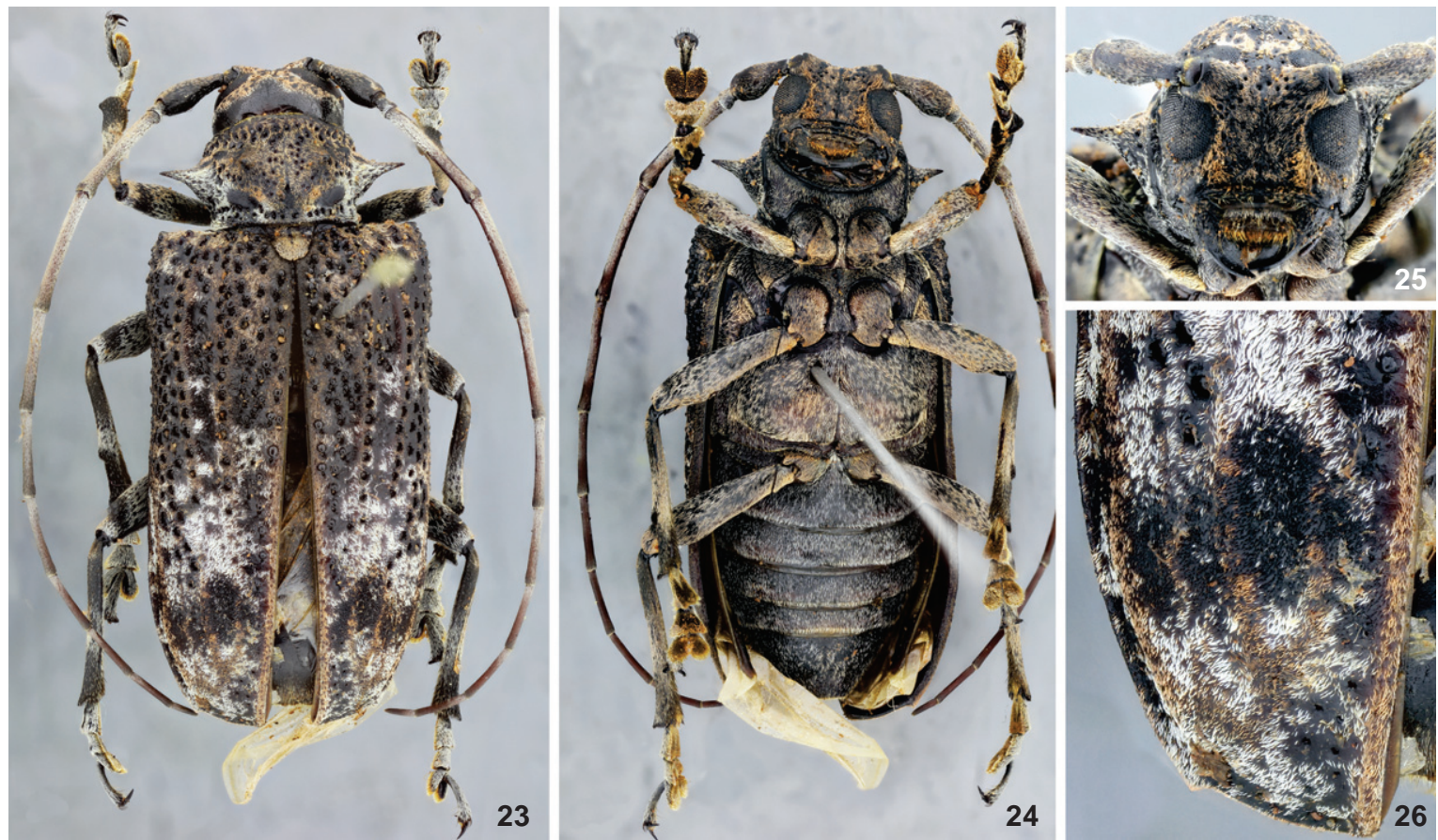

Figures 23-26. Polyrhaphis ju sp. nov., holotype female: (23) dorsal view; (24) ventral view; (25) head, frontal; (26) elytral apex.

depression in P. angustata); elytral apex projected on outer angle (conspicuously spiny in $P$. angustata).

The new species differs from $P$. gracilis Bates, 1862 by the following features: sutural apex of elytra without spine (with conspicuous spine in P. gracilis, rarely inconspicuous); with large tubercles between basal gibbosity and distal third of elytra (small in P. gracilis, frequently present only on basal half); distal fourth of elytra uniformly convex on surface (more plane in P. gracilis); apex of elytra not depressed between outer spine and suture (depressed in $P$. gracilis).

It differs from $P$. baloupae Santos-Silva et al., 2010 and $P$. lanei Santos-Silva et al., 2010 as follows: lateral spine of prothorax not directed forward (directed forward in P. baloupae and $P$. lanei); apex of elytra without depression between outer spine and suture (depressed in P. baloupae and P. lanei); distal fourth of elytra uniformly round on surface (flatter in $P$. baloupae and $P$. lanei); elytral apex projected on outer angle (conspicuously spiny in P. baloupae and P. lanei).

It differs from P. skillmani Wappes \& Santos-Silva, 2013 by the following features: area of head between antennal tubercles and clypeus with coarse punctures (punctures fine in P. skillmani); pronotum more abundantly punctate, particularly between tubercles and anterior margin (punctures sparser in P. skillmani); sutural apex of elytra rounded (projected in P. skillmani).

Polyrhaphis ju can be included in the alternative of couplet "20" from Santos-Silva et al. (2010):

20(19). Elytral apex projected. Brazil (Maranhão)..... P. ju sp. nov.
- Elytral apex distinctly spiny

21(20). Elytral tubercles moderately large (see fig. 64 in SANTOSSILVA et al. 2010) French Guiana

P. baloupae Santos-Silva et al., 2010

- Elytral tubercles small (see figs 66, 68 and 69 in Santos-SiLva et al. 2010). Ecuador, Bolivia, French Guyana, Brazil (Amazonas, São Paulo) P. gracilis Bates, 1862

\section{Pteropliini Thomson, 1860}

\section{Anobrium simplicis Galileo \& Martins, 2002}

Material examined. Brazil, Maranhão: Mirador (Parque Estadual Mirador, Base da Geraldina, 06 37'25"S, 45 52'08"W), 1 male, 12-20.X.2012, F.L. Oliveira, L.S. Santos \& C.F. Barros leg., light trap.

This species was described and is known only from Brazil (Goiás, São Paulo, and Paraná) (MonNé 2014b).

\section{Ataxia linearis (Bates, 1866)}

Material examined. BRAzIL, Maranhão: Bom Jardim (REBIO - Reserva Biológica do Gurupi), 2 males, 1 female, 2-11.IX.2010, F.L. Oliveira, J.C. Silva \& D.W.A. Marques leg.; 1 female, 211.IX.2010, D.W.A. Marques, E.A.S. Barbosa, J.A. Silva \& M.M. Abreu leg., Malaise trap.

This species was described from Brazil (Pará). It occurs in Bolivia, French Guiana, and Brazil (Pará, Rondônia, and Mato Grosso) (Monné 2014b). 


\section{ACKNOWLEDGMENTS}

We thank everyone involved in the field collection which resulted in the present work; Eugenio Nearns for the photos of the holotype of Limernaea picta. Ubirajara R. Martins and Maria Helena M. Galileo are research productivity fellows from Conselho Nacional de Desenvolvimento Científico e Tecnológico (CNPq).

\section{LITERATURED CITED}

Aurivillius, C. 1893. Neue oder wenig bekannte Coleoptera Longicornia. 4. Entomologisk Tidskrift 14: 177-186.

Aurivillius, C. 1912. Coleopterorum Catalogus, pars 39, Cerambycidae: Lamiinae. Berlin, W. Junk, p. 1-574.

Aurivillius, C. 1923. Coleopterorum Catalogus, pars 74, Cerambycidae: Lamiinae. Berlin, W. Junk, p. 323-704.

Bezark, L.G. \& M.A. Monné. 2013. Checklist of the Oxypeltidae, Vesperidae, Disteniidae and Cerambycidae (Coleoptera) of the Western Hemisphere. Rancho Dominguez, BioQuip Publications, 484p.

Bezark, L.G.; A. Santos-Silva \& U.R. Martins. 2011. New species of Rhinotragini and redescription of two species of Stultutragus Clarke (Coleoptera, Cerambycidae, Cerambycinae). Zootaxa 2965: 61-68.

Bezark, L.G.; U.R. Martins \& A. Santos-Silva. 2013. New species and new distribution records in Rhinotragini (Coleoptera: Cerambycidae: Cerambycinae). Zootaxa 3647 (1): 181-193.

BlackWELDER, R.E. 1946. Checklist of the coleopterous insects of Mexico, Central America, the West Indies and South America. Part 4. Bulletin of the United States National Museum 185: 551-763.

BosQ, J.M. \& A. Ruffinelli. 1951. Notas para el catálogo de los Cerambícidos del Uruguay. Comunicaciones Zoológicas del Museo de Historia Natural 3 (62): 1-32.

Buck, P. 1959. Cerambycidae in der Sammlung des Instituto Anchietano de Pesquisas. Pesquisas 3: 577-609.

Chemsak, J.A.; E.G. Linsley \& F.A. Noguera. 1992. Lista dos faunísticos de México. II. Los Cerambycidae y Disteniidae de Norteamérica, Centroamérica y las Indias Occidentales (Coleoptera). México, Universidad Nacional Autónoma, 204p.

Demez, P. \& J. Touroult. 2012. Contribution à la connaissance des longicornes du Pérou I. 59 nouveaux signalements pour le pays (Coleoptera, Cerambycidae). Les Cahiers Magellanes (NS) 6: 97-108.

Di Iorio, O. 2004. Aporte al catálogo de Cerambycidae del Paraguay (Insecta - Coleoptera). Parte IV. Addenda a Bosq (Partes I y II) y Viana (Parte III). Boletín del Museo Nacional de Historia Natural del Paraguay 15 (1-2): 9-65.

Duffy, E.A.J. 1960. A monograph of the immature stages of Neotropical timber beetles (Cerambycidae). London, British Museum (Natural History), VII+327p.
ErICHSON, W.F. 1848. Die Insekten, p. 533-617. In: R. SCHOMBURGK (Ed.). Reisen in Britisch-Guiana in den Jahren 1840-1844. Leipzig, Weber, vol. 3, VIII+533-1260.

Eya, B.K. \& J.A. Chemsak. 2005. Review of the genus Coleoxestia Aurivillius of Mexico and Central America. Part II. (Coleoptera, Cerambycidae). Les Cahiers Magellanes 45: 1-30.

Fabricius, J.C. 1793. Entomologia systematica emendata et aucta. Secundum classes, ordines, genera, species, adjectis synonymis, locis, observationibus, descriptionibus. Hafniae, C.G. Proft, 1(2): $x x+538$ p.

Galileo, M.H.M. \& U.R. Martins. 2003. Cerambycidae (Coleoptera) da Colombia. VI. Lamiinae com unhas tarsais divaricadas ou bífidas. Iheringia, Série Zoologia, 93 (3): 255-270

Gilmour, E.F. 1965. Catalogue des Lamiaires du Monde (Col. Céramb.). Verlag des Museums G. Frey Tutzing bei München, vol. 8, p. 559-655.

ICZN. 1999. International Code of Zoological Nomenclature. Londres, International Commission on Zoological Nomenclature, XXX+306p.

Júlio, C.E.A. \& M.A. Monné. 2001. Onychocerus Lepeletier \& Audinet-Serville, 1830 (Coleoptera, Cerambycidae, Lamiinae, Anisocerini): espécies novas e chave para identificação. Boletim do Museu Nacional (NS) Zoologia 443: 1-8.

LAMEERE, A.A. 1883. Liste des cérambycides, décrits postérieurement au catalogue de Munich. Annales de la Société Entomologique de Belgique 26: 1-78.

Maes, J.-M.; A. Allen; M.A. Monné \& F.T. Hovore. 1994. Catálogo de los Cerambycidae (Coleoptera) de Nicaragua. Revista Nicaraguense de Entomologia 27: 1-58.

Martins, U.R. 1967. Monografia da tribo Ibidionini (Coleoptera, Cerambycidae). Parte I. Arquivos de Zoologia 16 (1): 1-320.

Martins, U.R. 1968. Monografia da tribo Ibidionini (Coleoptera, Cerambycidae). Parte II. Arquivos de Zoologia 16 (2): 321 630.

MarTins, U.R. 1970. Monografia da tribo Ibidionini (Coleoptera, Cerambycidae). Parte V. Arquivos de Zoologia 16 (5): 11511342.

Martins, U.R. 1973. Notas sôbre Cerambycidae (Coleoptera), VIII. Papéis Avulsos de Zoologia 26 (16): 201-213.

Martins, U.R. 1997. Tribo Oemini, p. 3-155. In: U.R. Martins (Org.). Cerambycidae sul-americanos (Coleoptera). Taxonomia. São Paulo, Sociedade Brasileira de Entomologia, vol. 1.

MarTins, U.R. 1998. Tribo Ectenessini, p. 81-183. Cerambycidae sul-americanos (Coleoptera). Taxonomia. São Paulo, Sociedade Brasileira de Entomologia, vol. 2.

Martins, U.R. 2002. Tribo Achrysonini p. 37-144. In: Martins, U.R. (Org.). Cerambycidae sul-americanos (Coleoptera). Taxonomia. São Paulo, Sociedade Brasileira de Entomologia, vol 4 .

Martins, U.R. 2003. Tribo Piezocerini p. 65-201. In: Martins, U.R. (Org.). Cerambycidae sul-americanos (Coleoptera). Taxonomia. Curitiba, Sociedade Brasileira de Entomologia, vol. 6. 
Martins, U.R. 2005. Tribo Elaphidionini p. 1-394. In: Martins, U.R. (Org.). Cerambycidae sul-americanos (Coleoptera). Taxonomia. Curitiba, Sociedade Brasileira de Entomologia, vol. 7.

Martins, U.R. 2006. Tribo Hexoplonini, p. 21-211. In: Martins, U.R. (Org.). Cerambycidae sul-americanos (Coleoptera). Taxonomia. Curitiba, Sociedade Brasileira de Entomologia, vol. 8.

Martins, U.R. 2009. Tribo Ibidionini. Subtribo Compsina, p. 1199. In: U.R. MARTINS (Org.). Cerambycidae sul-americanos (Coleoptera). Taxonomia. Curitiba, Sociedade Brasileira de Entomologia, vol. 10.

Martins, U.R. \& M.H.M. Galileo. 1998. Revisão da tribo Aerenicini Lacordaire, 1872 (Coleoptera, Cerambycidae, Lamiinae). Arquivos de Zoologia 35 (1): 1-133.

Martins, U.R. \& M.H.M. Galileo. 2003. Tribo Obriini, p. 1-28. In: U.R. Martins (Org.). Cerambycidae sul-americanos (Coleoptera). Taxonomia. Curitiba, Sociedade Brasileira de Entomologia, vol. 6.

Martins, U.R. \& M.H.M. Galileo. 2004. Cerambycidae sulamericanos. Barcelona, Argania editio, Suplemento 1, 147p.

Martins, U.R. \& M.H.M. Galileo. 2007. Tribo Ibidionini, Subtribo Tropidina, p. 1-176. In: U.R. MARTINs (Org.). Cerambycidae sul-americanos (Coleoptera). Taxonomia. Curitiba, Sociedade Brasileira de Entomologia, vol. 9.

Martins, U.R. \& M.H.M. Galileo. 2012. Notas, novos registros e novas espécies de Ibidionini (Coleoptera, Cerambycidae). Revista Brasileira de Entomologia 56 (2): 199-209.

Martins, U.R. \& M.A. Monné. 2005. Tribo Cerambycini, Subtribo Sphallotrichina, p. 1-218. In: U.R. Martins (Org.). Cerambycidae sul-americanos (Coleoptera). Taxonomia. São Paulo, EDUSP, vol. 5.

Martins, U.R. \& A. Santos-Silva. 2012. On some species of Taeniotes Audinet-Serville, 1835 (Coleoptera: Cerambycidae: Lamiinae). The Pan-Pacific Entomologist 88 (1): 35-57.

Martins, U.R.; M.H.M. Galileo \& F.L. Oliveira. 2009a. Cerambycidae (Coleoptera) do estado do Maranhão, Brazil. Papéis Avulsos de Zoologia 49 (19): 229-247.

Martins, U.R.; M.H.M. Galileo \& F.L. Oliveira. 2009b. Cerambycidae (Coleoptera) do estado do Maranhão, Brazil. II. Papéis Avulsos de Zoologia 49 (38): 503-527.

Martins, U.R.; M.H.M. Galileo \& F.L. Oliveira. 2011. Cerambycidae (Coleoptera) do estado do Maranhão, Brazil. III. Papéis Avulsos de Zoologia 51 (18): 275-293.

Monné, M.A. 1993. Catalogue of the Cerambycidae (Coleoptera) of the Western Hemisphere. Part VI. Subfamily Cerambycinae: Tribes Eligmodermini, Callidiopini, Curiini, Graciliini, Obriini, Hyboderini, Eumichthini, Phlyctaenodini, Holopterini, Stenoderini, Pseudocephalini and Bimiini. São Paulo, Sociedade Brasileira de Entomologia, 47p.

Monné, M.A. 1994. Catalogue of the Cerambycidae (Coleoptera) of the Western Hemisphere. Part XVII. Subfamily Lamiinae: Tribes Anisocerini, Polyrhaphidini, Xenofreini, Acrocinini, Acanthoderini. São Paulo, Sociedade Brasileira de Entomologia, 110p.
Monné, M.A. 1995. Catalogue of the Cerambycidae (Coleoptera) of the Western Hemisphere. Part XX. Subfamily Lamiinae: Tribes Hemilophini, Aerenicini, Pretiliini, Falsamblesthiini, Calliini. São Paulo, Sociedade Brasileira de Entomologia, 120p.

Monné, M.A. 2005. Catalogue of the Cerambycidae (Coleoptera) of the Neotropical Region. Part II. Subfamily Lamiinae. Zootaxa 1023: 1-759.

Monné, M.A. 2014a. Catalogue of the Cerambycidae (Coleoptera) of the Neotropical Region. Part I. Subfamily Cerambycinae. Available online at: http://www.cerambyxcat.com [Accessed: 30/V/2014].

Monné, M.A. 2014b. Catalogue of the Cerambycidae (Coleoptera) of the Neotropical Region. Part II. Subfamily Lamiinae. Available online at: http://www.cerambyxcat. com [Accessed: 30/V/2014].

Monné, M.A. 2014c. Catalogue of the Cerambycidae (Coleoptera) of the Neotropical Region. Part III. Subfamilies Lepturinae, Necydalinae, Parandrinae, Prioninae, Spondylidinae and Families Oxypeltidae, Vesperidae and Disteniidae. Available online at: http:// www.cerambyxcat.com [Accessed: 30/V/2014].

Monné, M.A. \& E.F. GIESBERT. 1994. Checklist of the Cerambycidae and Disteniidae (Coleoptera) of the Western Hemisphere. Burbank, Wolfsgarden Books, 409p.

Monné, M.A. \& F.T. Hovore. 2005. Checklist of the Cerambycidae, or longhorned wood-boring beetles, of the Western Hemisphere. Rancho Dominguez, BioQuip Publications, 393p.

Monné, M.A. \& F.T. Hovore. 2006. Checklist of the Cerambycidae, or longhorned wood-boring beetles, of the Western Hemisphere. Rancho Dominguez, BioQuip Publications, 394p.

Monné, M.A. \& U.R. Martins. 1979. Colobotheini: sinonímias, gêneros e espécies novas (Coleoptera, Cerambycidae). Revista Brasileira de Biologia 39 (1): 31-35.

Monné, M.L. \& J.R.M. Mermudes. 2007. Revisão de Aegoschema Aurivillius (Coleoptera, Cerambycidae, Lamiinae). Revista Brasileira de Zoologia 24 (3): 559-564.

Monné, M.L.; M.A. MonnÉ; H.Y. Quintino; J.P. Botero; V.S. MAChado; C.A. Aragão; M.V.P. Simões \& M. Cupello. 2012. Inventário das espécies de Lamiinae (Insecta, Coleoptera, Cerambycidae) do Parque Nacional do Itatiaia, RJ, Brasil. Biota Neotropica 12 (1): 39-76.

Napp, D.S. 2007. Revisão do gênero Aglaoschema Napp (Coleoptera, Cerambycidae). Revista Brasileira de Zoologia 24 (3): 793-816.

Santos-Silva, A. \& M.H.M. Galileo. 2011. Sobre alguns Cerambycidae (Coleoptera) das coleções do Instituto Nacional de Pesquisas da Amazônia (INPA) e da Universidade Federal do Amazonas (UFAM): Parandrinae, Prioninae e Disteniinae. Les Cahiers Magellanes (NS) 3: 20-51.

Santos-Silva, A.; U.R. Martins \& G.L. TAVAKILIAN. 2010. Revisão do gênero Polyrhaphis Audinet-Serville (Coleoptera, Cerambycidae, Lamiinae). Papéis Avulsos de Zoologia 50 (30): 451-509. 
SCHÖNHERR, C. J. 1817. Synonymia Insectorum, oder: Versuch einer Synonymia aller bisher bekannten Insecten; nach Fabricii Systema Eleutheratorum \&c. geordnet. Lewerentzischen Buchdruekerey, Skara, vol. 1 (3), XI+506p.

SouzA, D.S. \& A.A. Silva. 2012. Cerambycidae (Insecta: Coleoptera) of the Parque Natural Municipal de Porto Velho, Rondônia, Western Amazon, Brazil. Biota Neotropica 12 (1): 237-240.

Tavakilian, G.L. 1996. III+19 estampas. In: V. Hequet (Ed.) Longicornes de Guyane. Caiena, ORSTOM, 36p.

Tavakilian, G.L. 2013. Limernaea picta Thomson, 1878. In: G.L. Tavakilian \& H. Chevillotte. Base de données Titan sur les Cerambycidés ou Longicornes. Available online at: http:/ /lully.snv.jussieu.fr/titan [Accessed: 30.III.2014]

Tavakilian, G.L. \& G.-L. NÉouze. 2004. Les Desmiphora AudinetServille, 1835, de Guyane; descriptions d'espèces nouvelles (Coleoptera, Cerambycidae, Lamiinae). Coléoptères 10 (5): 49-68.

Thomson, J. 1878a. Typy cerambycidarum (2e Mémoire). Cerambycitae. Revue et Magasin de Zoologie 3 (6):1-33.

Thomson, J. 1878b. Typy cerambycidarum musei Thomsoniani. Paris, Deirolle, 21p.

VianA, M.J. 1972. Aporte al catálogo de Cerambycidae del Paraguay (Insecta, Coleoptera). Revista del Museo Argentino de Ciencias Naturales "Bernardino Rivadavia"
(Entomologia) 3 (4): 207-405.

VILLIERS, A. 1971. Cerambycidae (Coleoptera) récoltés en Guyane Française par la mission du Muséum national d'Histoire naturelle. Annales de la Société Entomologique de France (N.S.) 7 (2): 343-350.

Wappes, J.E.; R.F. Morris ; E.H. Nearns \& M.C. Thomas. 2006. Preliminary checklist of Bolivian Cerambycidae (Coleoptera). Insecta Mundi 20 (1-2): 1-45.

ZajcIW, D. 1960. Longicórneos novos para a fauna do Brazil (Col. Cerambycidae). II. Revista Brasileira de Entomologia 9: 69-79.

ZAJCIW, D. 1965. Contribuições para o estudo da fauna dos longicórneos do estado da Paraíba (Coleoptera, Cerambycidae). Boletim da Sociedade Cearense de Agronomia 6: 5-21.

Zajciw, D. 1967. Contribuição para o estudo da fauna dos longicórneos do Estado do Maranhão. Boletim da Sociedade Cearense de Agronomia 8: 1-12.

ZajciW, D. 1972. Contribuição para o estudo da fauna de longicórneos do Parque Nacional do Itatiaia (Coleoptera, Cerambycidae). Brasil Florestal 3: 40-72.

ZAJCIW, D. 1974. Contribuição para o estudo dos longicórneos (Coleoptera, Cerambycidae) das florestas do Estado do Espírito Santo e principalmente da Reserva Biológica "Soóretama". Boletim Técnico do Instituto Brasileiro de Desenvolvimento Florestal 4: 37-91.

Submitted: 17.IX.2014; Accepted: 26.XI.2014.

Editorial responsibility: Gabriel L.F. Mejdalani

ZOOLOGIA 31 (6): 599-620, December, 2014 